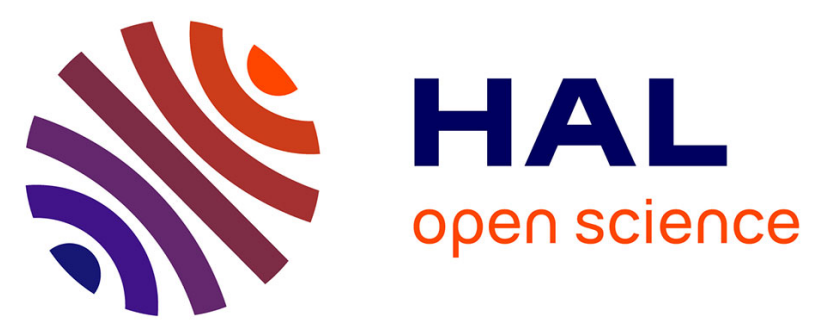

\title{
New Operando IR Technique to Study the Photocatalytic Activity and Selectivity of TiO 2 Nanotubes in Air Purification: Influence of Temperature, UV Intensity, and VOC Concentration
}

Mohamad El-Roz, Monika Kus, Pegie Cool, Frederic Thibault-Starzyk

\section{To cite this version:}

Mohamad El-Roz, Monika Kus, Pegie Cool, Frederic Thibault-Starzyk. New Operando IR Technique to Study the Photocatalytic Activity and Selectivity of TiO 2 Nanotubes in Air Purification: Influence of Temperature, UV Intensity, and VOC Concentration. Journal of Physical Chemistry C, 2012, 116 (24), pp.13252-13263. 10.1021/jp3034819 . hal-02430232

\section{HAL Id: hal-02430232 \\ https://hal.science/hal-02430232}

Submitted on 5 Oct 2021

HAL is a multi-disciplinary open access archive for the deposit and dissemination of scientific research documents, whether they are published or not. The documents may come from teaching and research institutions in France or abroad, or from public or private research centers.
L'archive ouverte pluridisciplinaire HAL, est destinée au dépôt et à la diffusion de documents scientifiques de niveau recherche, publiés ou non, émanant des établissements d'enseignement et de recherche français ou étrangers, des laboratoires publics ou privés. 


\title{
New operando-IR technique to study the photocatalytic activity
} and selectivity of $\mathrm{TiO}_{2}$-nanotubes in air purification: influence of temperature, UV intensity and VOCs concentration.

\author{
Mohamad El-Roz*a, Monika Kus ${ }^{\text {b }}$, Pegie Cool ${ }^{b}$, Frederic Thibault-Starzyk ${ }^{a}$ \\ *Corresponding authors: mohamad.el-roz@ensicaen.fr
}

${ }^{a}$ Laboratoire Catalyse et Spectrochimie (LCS), ENSICAEN, Université de Caen, CNRS , 6, Bd du Maréchal Juin, 14050 Caen Cedex, France. Fax: +33(0)231 4528 22, Tel: +33(0)231 452732 ,E-mail: mohamad.el-roz@ensicaen.fr

${ }^{\mathrm{b}}$ Laboratory of Adsorption and Catalysis, Department of Chemistry, University of Antwerpen, Universiteitsplein 1, B-2610 Wilrijk, Belgium.

\begin{abstract}
The photooxidation of methanol, n-hexane and carbon monoxide using $\mathrm{TiO}_{2^{-}}$ nanotubes (TNTs) has been investigated by a new IR-operando technique. Following the photocatalytic reaction by time resolved IR spectroscopy coupled with mass spectrometry (MS) allowed a surface study of the photocatalyst with on line analysis of the products. The identification of the species adsorbed on the photocatalyst surface and those detected in the gas phase led to further clarify the photooxidation mechanisms. The characterization of the photocatalyst has been performed by IR, Raman, UV-visible, XRD, $\mathrm{N}_{2}$-sorption, SEM and TEM techniques. The activity and selectivity of the photocatalyst have been determined by quantitative studies using gas-IR and MS. For comparison, photooxidation reactions, using $\mathrm{TiO}_{2}-\mathrm{P} 25$ as reference, have been performed under the same conditions. The influence of different parameters such as temperature, VOC concentrations and UV irradiation intensities on the reactivity and selectivity of the photocatalytic reaction has been investigated. The
\end{abstract}


temperature effect has been shown by TPD measurements (from RT to $200^{\circ} \mathrm{C}$ ). The TNTs material showed a higher reactivity and $\mathrm{CO}_{2}$-selectivity in comparison with $\mathrm{TiO}_{2}-\mathrm{P} 25$.

Keywords: $\mathrm{TiO}_{2}$ nanotubes, Photocatalysis, operando-IR, VOC and carbon monoxide photooxidation, temperature and VOC concentration effect.

\section{Introduction}

The decontamination of air in closed spaces such as aircrafts, air-conditioned spaces, etc..., from volatile organic contaminants/compounds (VOC) attracts special attention due to its economic and health interests. The use of heterogeneous catalysts, largely employed for the control and treatment of exhaust gases, presents one of the key features for such treatment. Indeed, the reaction on the catalyst can be induced either by heating, or by UV light when using a photocatalyst. This latter presents many advantages such as low cost and low environmental impact, and $\mathrm{TiO}_{2}$ is considered as the most promising catalyst for this purpose. $\mathrm{TiO}_{2}$ is cheap, resistant to photocorrosion, photostable and non toxic. It is easy to prepare, environmentally friendly and has a low band gap energy. ${ }^{1,2,3}$ With new environmental issues, it is expected that applications for $\mathrm{TiO}_{2}$ will grow with a high speed. In particular, the improvement of $\mathrm{TiO}_{2}$ activity in organic photodegradation processes is needed for large scale industrial treatment processes such as waste water treatment and de-VOCs ${ }^{4,5,6}$. Titania nanotubes (TNTs) have been proven to be highly promising for potential applications in various fields ${ }^{7,8}$. Titania nanotubes layers were shown recently to be more efficient in the photocatalytic conversion of organic azo dyes than common photocatalysts ${ }^{4,9}$. In the present work, $\mathrm{TiO}_{2}$-nanotubes (TNTs) have been prepared by a hydrothermal method according to $\mathrm{S}$. Ribbens et al. ${ }^{10}$, and studied in the photooxidation of methanol, n-hexane and carbon monoxide by a new operando IR technique. The common point of the air pollutants chosen $\left(\mathrm{CH}_{3} \mathrm{OH}, \mathrm{C}_{6} \mathrm{H}_{14}\right.$ and $\left.\mathrm{CO}\right)$ is their toxicity even at low concentration. The comparison of 
methanol and n-hexane photooxidation allows investigating the influence of hydrophilic/hydrophobic ratio and hydrocarbon chain length on the photooxidation activity. In order to estimate the activity of TNTs in gas phase photooxidation reactions, a well known photocatalyst, $\mathrm{TiO}_{2}-\mathrm{P} 25$ from Degussa, has been used. The influence of various parameters, such as the temperature, the UV irradiation intensity and the concentrations of VOCs or CO was studied in real time. The present work shows the interest of operando IR to perform photocatalytic studies, on self supporting wafers of the catalysts and in gas flow in conditions very close to those of the real reaction.

\section{Experimental part}

\section{Synthesis}

Titanium based nanotubes were synthesised using a hydrothermal method. In a typical preparation $4,5 \mathrm{~g}$ of commercial $\mathrm{TiO}_{2}$ powder was dispersed in $80 \mathrm{ml}$ of $10 \mathrm{M} \mathrm{NaOH}$ solution under vigorous stirring. The mixture was stirred for 1 hour and transferred to an autoclave with internal volume $150 \mathrm{ml}$, followed by hydrothermal treatment at $150^{\circ} \mathrm{C}$ for 48 hours. After 48 hours the autoclave was quenched to room temperature and the product was recovered by centrifugation. The precipitation was washed 3 times with distilled water. Afterwards the wet cake was dispersed in $240 \mathrm{ml}$ of $0,1 \mathrm{M} \mathrm{HCl}$ solution and stirred for $30 \mathrm{~min}$. H-tubes were recovered by centrifugation and washed until the $\mathrm{pH}$ reached 1 . The precipitate was washed 3 times with distilled water and 2 times with ethanol. The product was calcined at $350^{\circ} \mathrm{C}$ for $6 \mathrm{~h}$ to obtain mixed phase nanotubes. 


\section{Characterisation}

\section{$X$-ray diffraction}

In order to investigate the crystallinity and phase purity of the samples, calcined and assynthesized $\mathrm{TiO}_{2}$-nanotubes crystals have been characterized, and compared to $\mathrm{TiO}_{2}-\mathrm{P} 25$ and $\mathrm{TiO}_{2}$-rutile (99.9\% of purity), by X-ray diffraction (XRD) on a PANanalytical (X-Pert Pro) diffractometer with $\mathrm{CuK} \alpha 1$ source $(\lambda=0.15406 \mathrm{~nm}, 40 \mathrm{kV}, 30 \mathrm{~mA})$.

\section{SEM and TEM}

The morphological features and the chemical analyses of the samples were studied using Scanning Electron Microscope (SEM, Hitachi S3460) and Transmission Electron Microscope (TEM, Phillips CM 20) operating at 200kV.

\section{Nitrogen sorption}

Nitrogen sorption measurements of $\mathrm{TiO}_{2}$ samples were carried out at $-196^{\circ} \mathrm{C}$ on a Micromeritics ASAP 2020 micropore analyse. The samples were degassed at $150^{\circ} \mathrm{C} \mathrm{K}$ for 24 h. Surface areas were calculated using BET equation.

\section{$U V$-vis $D R$}

UV-Vis DR measurements were performed on Thermo-electron evolution 500 UV-Vis spectrometer equipped with RSA-CU40 Diffuse Reflectance cell. From UV-Vis DR spectra information over the band gap energy can be obtained.

\section{Raman}

Raman spectra were recorded on a Nicolet Nexus FT-Raman spectrometer with an InGaAs detector and a $1064 \mathrm{~nm} \mathrm{Nd:YAG} \mathrm{laser}$ 


\section{Acidic properties}

The acidic properties of the resulting materials were investigated by temperature desorption (TD) of pyridine followed by IR. Powders were pressed $\left(\sim 10^{7} \mathrm{~Pa}\right)$ into self-supported discs $(2$ $\mathrm{cm}^{2}$ area, 9-10 $\mathrm{mg} . \mathrm{cm}^{-2}$ ) and placed in an IR cell equipped with $\mathrm{KBr}$ windows. IR spectra have been recorded using a Nicolet 6700 IR spectrometer equipped with a MCT detector and an extended-KBr beam splitter. Spectra were recorded in the $400-5500 \mathrm{~cm}^{-1}$ range at $4 \mathrm{~cm}^{-1}$ with 128 scans. A movable quartz sample holder allowed placing the self-supported discs in the infrared beam for recording spectra, and moving it into a furnace at the top of the cell for thermal treatment. ${ }^{11}$ Pyridine (Py) adsorption was performed by introduction of doses inside the infrared cell containing the previously activated (under vacuum at $200^{\circ} \mathrm{C}$ for $5 \mathrm{~h}$ ) selfsupported discs. After introduction of each dose of Py, the samples were heated at $200^{\circ} \mathrm{C}$ for 10 min to allow diffusion toward all accessible sites before recording the spectrum. Infrared spectra were recorded after Py saturation (1.33 mbar at equilibrium) followed by evacuation at $200^{\circ} \mathrm{C}$ to remove physisorbed species. In all experiments, analytical grade pyridine (Aldrich) was used after water trapping with molecular sieve 3A. The calculation of the IR band surface area has been performed using Omnic v8.2 software. The values were normalized for the same samples weight $(20 \mathrm{mg})$.

\section{Conditions for Photocatalytic operando test}

The photocatalytic oxidation of methanol has been followed by IR spectroscopy. The powder of the desired catalyst was pressed into self-supported wafers $(\varnothing=16 \mathrm{~mm}, \mathrm{~m} \sim 10$ $\mathrm{mg} / \mathrm{cm}^{2}$ ). IR spectra were collected with a Nicolet 5700 FT-IR spectrometer (64 scans/spectrum) equipped with a MCT detector. The operando system is connected to a flow set-up. Gases are introduced into the lines (heated at $60^{\circ} \mathrm{C}$ ) by mass flow controllers. The two gas mixtures, so called "activation" and "reaction" flows, can be prepared and sent 
independently to the reactor cell. The "Sandwich" reactor-cell used in this study is an evolution of the operando cell developed by Saussey et al. ${ }^{12}$, which has proven its reliability over many years of operando studies ${ }^{12,13}$. It is made of a stainless steel cylinder that carries a toroidal sample holder in its centre, where the catalyst self supporting wafer is placed. Tightness is obtained by Kalrez@ O-rings, and the dead volume (typically defined as the residual space between each sample face and the windows) is reduced to about $0.4 \mathrm{ml}$ by filling the empty space with $\mathrm{KBr}$ windows placed on each side of the sample holder. The surface analysis is made possible without superposition of the gas phase signal and fluid dynamics is very similar to that inside a honeycomb monolith. Gases are introduced on the sample by $1 / 8$ " OD pipe and collected on the opposite side of the sample holder. More details can be found in the following references ${ }^{14,15}$. For this specific photocatalytic oxidation study, UV irradiation was carried out with a polychromatic light of a Xe-Hg lamp (LC8 spot light Hamamatsu, L10852, 200 W). It has been performed by using a UV-light guide (A10014-500110) mounted at the entrance of modified IR operando cell as presented in Scheme 1 in order to establish a "homogeneous" irradiation. UV irradiation intensity $\left(\mathrm{I}_{0}\right)$ has been measured using a light power meter (from Hamamatsu).

In such a configuration, at atmospheric pressure, and small amounts of VOC to be removed, a low partial pressure of VOC was established using a saturator at a carefully controlled temperature. The gas mixture composition was then fixed at 0.01 to 0.5 vol.\% methanol, n-hexane or CO, 20 vol. $\% \mathrm{O}_{2}$ in $\mathrm{Ar}$ and the total flow was adjusted to $25 \mathrm{~cm}^{3} / \mathrm{min}$. The analysis of the outlet gases was performed by means of a Pfeiffer Omnistar mass spectrometer. Likewise, FT-IR spectra of the gas phase were collected using a gas microcell. 


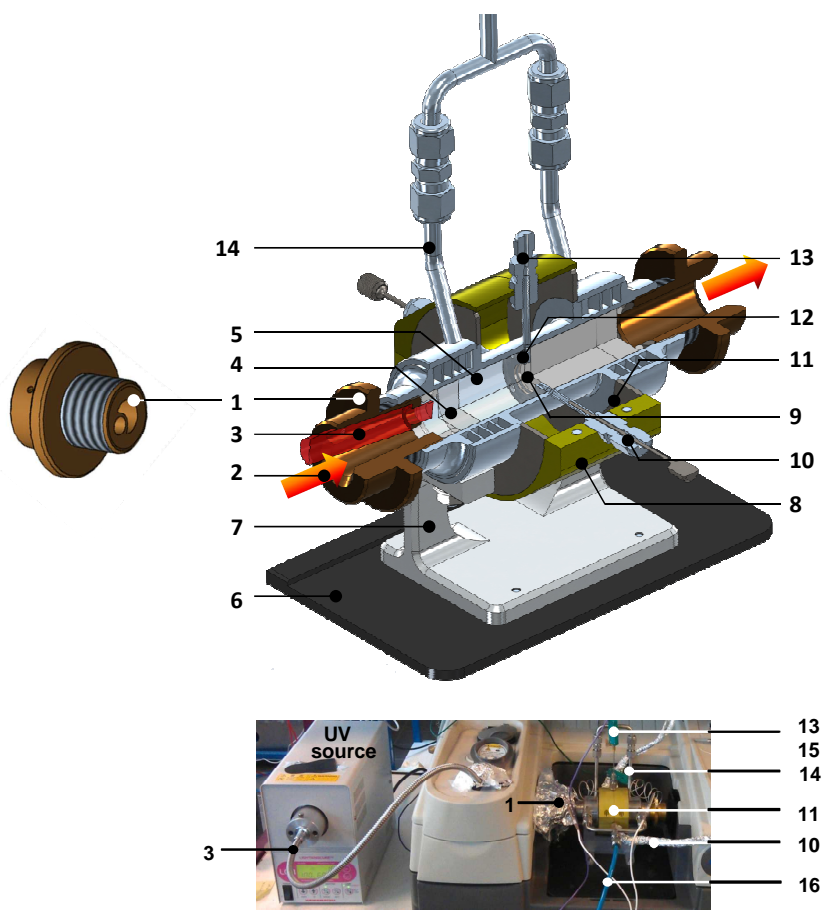

Scheme 1. The "sandwich" reactor-IR cell modified for studying UV photocatalysis. (1) Adjusting nut for airtightness (modified for UV-guid position), (2) IR beam, (3) UV-light guid, (4) Kalrez O-ring, (5) $\mathrm{KBr}$ windows, (6) Spectrometer base-plate, (7) IR cell support, (8) Oven location, (9) Sample (wafer), (10) Gas inlet, (11) External shell, (12) Wafer holder, (13) Thermocouple location, (14) Air cooling outlet, (15) Gas outlet, (16) Air cooling inlet.

Photooxidation reaction at RT where performed after a photoactivation at RT under $20 \% \mathrm{O}_{2} / \mathrm{Ar}$. Photooxidations at variable temperature were carried out after activation of the pellet at $200 \mathrm{C}$ for two hours.

The photooxidation of methanol $(\mathrm{MeOH})$ has been performed using $\mathrm{TiO}_{2}-\mathrm{P} 25$ and TNTs as photocatalyst under the same conditions (concentration, temperature, flow rate...). The concentration was fixed at $5040 \mathrm{ppm}$ of $\mathrm{MeOH}$ in $20 \% \mathrm{O}_{2}$ in $\mathrm{Ar}$ at $25 \mathrm{~cm}^{3} / \mathrm{min}$. The UV intensity $\left(\mathrm{I}_{0}\right)$ was estimated to $\sim 2 \mathrm{~mW} / \mathrm{cm}^{2}$ ( $\sim 20 \%$ of the lamp intensity). 


\section{Results and discussion}

\section{Characterization}

The nanomorphology of calcined $\mathrm{TiO}_{2}$ nanotubes (TNTs) is confirmed using scanning electron microscope (SEM) and transmission electron microscopy (TEM). The results are presented in Figure 1. The average length of the tubes was found around $90 \mathrm{~nm}$.

< Figure 1 here>

Figure 2 presents the $\mathrm{X}$-ray diffraction patterns of $\mathrm{TiO}_{2}$-rutile, $\mathrm{TiO}_{2}-\mathrm{P} 25$, as synthesized and calcined TNTs. The results show that X-ray diffraction patterns of TNTs correspond to $\mathrm{TiO}_{2}$ anatase phase and no significant modification has been observed after calcination. The broadening of X-ray peaks observed, in comparison with $\mathrm{TiO}_{2}-\mathrm{P} 25$ could be assigned to the nanocrystalline nature of the TNTs nanotubes. Moreover, after calcination at $350^{\circ} \mathrm{C}$, no rutile phase has been observed. For reasons of comparison also the XRD pattern of rutile phase is reported in Figure 2.

$<$ Figure 2 here>

Raman spectra are presented in Figure 3. Spectra of the calcined sample are compared to the spectra of the sample before calcination. The peaks at Raman shifts 188, 273, 369, 449 and $663 \mathrm{~cm}^{-1}$ reveal the presence of a trititanate structure for the non-calcined form. After the calcination process at $350^{\circ} \mathrm{C}$ peaks at 399,510 and $639 \mathrm{~cm}^{-1}$ are appearing which are characteristic for the anatase form of $\mathrm{TiO}_{2}$. This indicates that the sample undergoes incomplete transformation from $\mathrm{H}_{2} \mathrm{Ti}_{3} \mathrm{O}_{7}$ to anatase $\mathrm{TiO}_{2}$ during the calcination procedure.

< Figure 3 here> 
The $\mathrm{N}_{2}$-sorption results show a surface area of TNTs $\left(230 \mathrm{~m}^{2} / \mathrm{g}\right) 4$ times higher with respect to $\mathrm{TiO}_{2}-\mathrm{P} 25\left(55 \mathrm{~m}^{2} / \mathrm{g}\right)$ (Figure 4). The hysteresis present at 0.8 to 0.9 in the case of TNTs assigned to the textural porosity of this nanotube.

$<$ Figure 4 here $>$

The photocatalytic activity of a material is determined by the band gap energy, defect sites and surface area of the sample. Band gap energy can be calculated from UV-Vis DR spectra. In Figure 5 spectra of $\mathrm{TiO}_{2}-\mathrm{P} 25$ (a), $\mathrm{TiO}_{2}$-nanotube after calcination (b) and $\mathrm{TiO}_{2}$-nanotube before calcination (c) are compared. The band gap energies for the samples are respectively 3.07, 3.21 and $3.27 \mathrm{eV}$. $\mathrm{TiO}_{2}-\mathrm{P} 25$ sample has lower band gap energy than the prepared nanotube samples. According to the literature, this slight difference could be assigned to the $\mathrm{TiOH}$ content and $\mathrm{Ti}(\mathrm{III}) / \mathrm{Ti}(\mathrm{IV})$ ratio present in the different samples which could affect the $\mathrm{TiO}_{2}$ band gap values. ${ }^{16}$ The photocatalytic activity depends also on the surface area which is much higher for the $\mathrm{TiO}_{2}$-nanotube samples.

$<$ Figure 5 here $>$

\section{Acidic properties}

The IR spectra (collected under dry air at room temperature) showed that the water content (calculated using the band at $1630 \mathrm{~cm}^{-1}$ ) is about three times higher in TNTs than in $\mathrm{TiO}_{2}-\mathrm{P} 25$. After activation under vacuum at $200^{\circ} \mathrm{C}$, the IR spectra showed too separate bands at $\sim 3720 \mathrm{~cm}^{-1}$ and $\sim 3670 \mathrm{~cm}^{-1}$ (Figure 6) assigned to $\mathrm{Ti}(\mathrm{III}) \mathrm{OH}$ and $\mathrm{Ti}(\mathrm{IV}$ )OH respectively ${ }^{17,18}$. The $\mathrm{TiOH}$ band area is twice higher in TNTs material which explains the higher hydrophilicity of this photocatalyst in comparison to $\mathrm{TiO}_{2}-\mathrm{P} 25$.

< Figure 6 here> 
The IR spectra of the photocatalyst surfaces after pyridine adsorption, and evacuation at $200^{\circ} \mathrm{C}$ under vacuum $\left(\sim 10^{-6} \mathrm{mbar}\right)$, are presented in Figure 7 . New bands appeared at 1610, 1575 and $\sim 1445 \mathrm{~cm}^{-1}$, assigned to pyridine molecules (Py) adsorbed on Lewis acid centers (Ti cation sites), and at $1490 \mathrm{~cm}^{-1}$, assigned to Py on Brønsted (Py-B) and/or Lewis (Py-L) acidic sites ${ }^{19}$. The bands at $1610 \mathrm{~cm}^{-1}$ and $1445 \mathrm{~cm}^{-1}$ are assigned to pyridine molecules chemisorbed by the interaction between the nitrogen lone pair and the substrate surface ${ }^{19,20,21}$. Table 1 summarizes the area of Py-B and Py-L bands. More Py was adsorbed on the TNTs than on $\mathrm{TiO}_{2}-\mathrm{P} 25$ surface (1.5 to 2.5 times), possibly because of the higher amount of $\mathrm{TiOH}$ on TNTs (Figure 6). Looking at the intensities for the $\mathrm{OH}$ bands, the $\mathrm{Ti}(\mathrm{III}) \mathrm{OH}_{(\mathrm{TNTs})} /$ $\mathrm{Ti}(\mathrm{III}) \mathrm{OH}_{(\mathrm{TiO}-\mathrm{P} 25)}$ ratio was about 1.3 , close to the ratio of the area of the band at $1610 \mathrm{~cm}^{-1}$ (1.4) on the two solids. For Ti(IV)OH $\mathrm{OH}_{(\mathrm{TNTs})} / \mathrm{Ti}(\mathrm{IV}) \mathrm{OH}_{(\mathrm{TiO}-\mathrm{P} 25)}$ (band at $3670 \mathrm{~cm}^{-1}$ ), a value of 2.6 has been found, close to that obtained for the area of the band at $1448 \mathrm{~cm}^{-1}$ (2.5) on the two samples (Table 1). This indicates that the bands at 1610 and $1448 \mathrm{~cm}^{-1}$ could be assigned to pyridine molecules adsorbed on $\mathrm{Ti}(\mathrm{III}) \mathrm{OH}$ sites and on $\mathrm{Ti}(\mathrm{IV}) \mathrm{OH}$ sites, respectively. A thermo desorption would be useful to confirm this hypothesis, but it is unfortunately not possible due to the degradation of pyridine on $\mathrm{TiO}_{2}$ surface at $\mathrm{T}>225^{\circ} \mathrm{C}$ (coke formation on $\mathrm{TiO}_{2}$ surface has been observed at high temperature). On the other hand the evolution of $\mathrm{OH}$ peak height, on TNTs sample, after pyridine adsorption at different temperatures has been followed (Figure 7B). The result shows an increase of the band at $3720 \mathrm{~cm}^{-1}$ assigned to pyridine desorption. A slow decrease of the band at $3670 \mathrm{~cm}^{-1}$ was observed, assigned to coke formation. This is in good agreement with a lower acidity for $\mathrm{Ti}(\mathrm{III}) \mathrm{OH}$ than for $\mathrm{Ti}(\mathrm{IV}) \mathrm{OH}$ sites.

$<$ Figure 7 here> 


\section{Methanol photooxidation}

\section{Photooxidation reactivity and temperature effect}

The IR spectra of TNTs during methanol adsorption are presented in Figure 8A. A decrease of the band at $3820-3600 \mathrm{~cm}^{-1}$ is observed ( $(\mathrm{TiO}-\mathrm{H})$ vibration mode), simultaneously with an increase of a broad band at $3660-3000 \mathrm{~cm}^{-1}$, assigned to the vibration band of $\mathrm{H}$-bonded TiOH (methanol adsorption on $\mathrm{TiOH}$ ). Figure 8B shows the IR spectra of $\mathrm{TiO}_{2}-\mathrm{P} 25$ and $\mathrm{TNTs}$ samples monitored at RT after saturation with methanol (MeOH) before UV irradiation. Four main bands are observed between 3000 and $2700 \mathrm{~cm}^{-1}$ assigned to $\mathrm{CH}_{3}$ (methanol) vibration modes. The bands at 2920 and $2820 \mathrm{~cm}^{-1}$ correspond respectively to the $v_{\mathrm{s}}\left(\mathrm{CH}_{3}\right)$ and $\mathrm{v}_{\mathrm{as}}\left(\mathrm{CH}_{3}\right)$ vibration modes of dissociatively chemisorbed methanol (with rupture of the $\mathrm{O}-\mathrm{H}$ bond) on $\mathrm{TiO}_{2}$ surface $22,23,24$. The relatively high intensity of these two bands on TNTs compared to those on $\mathrm{TiO}_{2}-\mathrm{P} 25$ shows a high methanol chemisorption on TNTs surface (in agreement with the high amount of $\mathrm{Ti}(\mathrm{IV}) \mathrm{OH}$ sites on this material). The additional bands situated at 2945 and $2840 \mathrm{~cm}^{-1}$ are attributed to $v_{\mathrm{s}}\left(\mathrm{CH}_{3}\right)$ and $\mathrm{v}_{\mathrm{s}}\left(\mathrm{CH}_{3}\right)$ vibration modes of methanol molecularly adsorbed on $\mathrm{TiO}_{2}$ surfaces ${ }^{22,23,24}$.

$<$ Figure 8 here>

Figure 9 shows the IR spectra vs. time (and temperature) for the gas phase during the photooxidation of methanol on TNTs (A) and $\mathrm{TiO}_{2}-\mathrm{P} 25$ (B) as photocatalysts. It shows a spontaneous decrease of methanol bands after UV irradiation. New bands appearing during the photooxidation were assigned to $\mathrm{CO}_{2}\left(2400-2200 \mathrm{~cm}^{-1}\right),-\mathrm{C}=\mathrm{O}\left(1820-1670 \mathrm{~cm}^{-1}\right)$ and $\mathrm{C}-\mathrm{H}$ 
vibration modes $\left(1275-1100 \mathrm{~cm}^{-1}\right)^{25}$. The IR-gas spectra during photooxidation (at RT) are presented in Figure 10. IR spectra of formaldehyde, methylformate and formic acid are also presented, and show that carbonyl species could be a mixture of the three: the $\mathrm{CH}$ band at $1275-1100 \mathrm{~cm}^{-1}$ assigned to $r(\mathrm{CH})$ vibration mode is not present in the case of pure formaldehyde ${ }^{26}$. The quantification of carbonyl species is not possible due to the overlapping IR bands.

$<$ Figure 9 here>

< Figure 10 here>

The quantification of methanol has been performed using the area of the $1090-950 \mathrm{~cm}^{-1}$ band assigned to the $v(\mathrm{C}-\mathrm{O})$ vibration mode of methanol. Methanol conversion has been estimated with the following formula:

$$
\text { Conversion }(\%)=\frac{\left(A_{0}-A_{t(T)}\right)}{A_{0}} \cdot 100 \%
$$

with:

$\mathrm{A}_{0}=$ the band area of $\mathrm{MeOH}$ (in the gas phase) before photooxidation $\mathrm{A}_{\mathrm{t}(\mathrm{T})}=$ the band area of $\mathrm{MeOH}$ during photooxidation at time " $\mathrm{t}$ " (or at Temperature " $\mathrm{T}$ ")

The selectivity of $\mathrm{MeOH}$ transformation to $\mathrm{CO}_{2}$ has been calculated using the band area of $\mathrm{CO}_{2}$ measured during a complete and total photocombustion of $5040 \mathrm{ppm}$ of $\mathrm{MeOH}$ under special irradiation conditions $\left(\mathrm{I}_{0}=11 \mathrm{~mW} / \mathrm{cm}^{2}\right)$ : photocombustion is then $100 \%$ selective $\left(\mathrm{CO}_{2}\right.$ production) and the observed band area corresponds to $\sim 5000 \mathrm{ppm}$ of $\mathrm{CO}_{2}$. This result has been used for estimating $\mathrm{CO}_{2}$ concentration during the photooxidation of $5040 \mathrm{ppm}$ $\mathrm{MeOH}$ under different conditions. The $\mathrm{CO}_{2}$-selectivity has been calculated as follows: 


$$
\mathrm{CO}_{2}-\operatorname{selectivity}(\%)=\frac{n_{\mathrm{CO}_{2}}}{n_{\mathrm{MeOH}-\text { converted }}} \cdot 100 \%
$$

with:

$n_{\mathrm{CO}_{2}}=$ amount of $\mathrm{CO}_{2}$ produced in mole.

$n_{\mathrm{MeOH}-\mathrm{converted}}=$ amount of methanol converted in mole.

Figure 11 illustrates the effect of temperature on methanol conversion and $\mathrm{CO}_{2}$ selectivity in the case of TNTs (Figure 11-A) and $\mathrm{TiO}_{2}-\mathrm{P} 25$ (Figure 11-B). TNTs are 1.5 to 2 times higher compared to $\mathrm{TiO}_{2}-\mathrm{P} 25$, with higher $\mathrm{CO}_{2}$-selectivity ( $\sim 1.5$ times more, see Table 2 ). The increase of temperature led to an increase of methanol conversion with a maximum at $\sim 180^{\circ} \mathrm{C}$ (Figure 11). Experiments have been performed at less than $200^{\circ} \mathrm{C}$ in order to prevent the transformation of the $\mathrm{TiO}_{2}$ phase, especially in the case of $\mathrm{TiO}_{2}-\mathrm{P} 25$, as mentioned in the literature. A decrease in $\mathrm{CO}_{2}$ selectivity (from $85 \%$ to $60 \%$ ) on TNTs has been observed at $\mathrm{T}>35{ }^{\circ} \mathrm{C}$, with a plateau at $\sim 60 \%$ for $\mathrm{T}>90^{\circ} \mathrm{C}$. For $\mathrm{TiO}_{2}-\mathrm{P} 25$, no significant effect of the temperature on $\mathrm{CO}_{2}$ selectivity was observed. The small time lag between $\mathrm{CO}_{2}$ detection and methanol conversion ( $\sim \mathrm{min})$ is assigned to the ignition of methanol desorption from $\mathrm{TiO}_{2}$ surface leading to a momentary increase of methanol in the gas phase. This is confirmed by the IR spectra of $\mathrm{TiO}_{2}$ before and during methanol photooxidation when significant decrease of adsorbed methanol has been observed immediately upon switching UV-irradiation on.

\section{< Figure 11 here>}

In order to confirm these results, methanol conversion has been calculated using the MS signal for methanol before and during irradiation: 


$$
\text { Conversion }(\%)=\frac{\left(I_{0}-I_{t(T)}\right)}{I_{0}} \cdot 100 \%
$$

with:

$\mathrm{I}_{0}=$ the MS intensity of $\mathrm{m} / \mathrm{z}=31$ signal detected by MS before photooxidation

$\mathrm{I}_{\mathrm{t}(\mathrm{T})}=$ the MS intensity of $\mathrm{m} / \mathrm{z}=31$ signal detected by MS during photooxidation at time $\mathrm{t}$ (or temperature T).

In addition, the MS signal for $\mathrm{H}_{2} \mathrm{O}$ at $\mathrm{m} / \mathrm{z}=18$ and for $\mathrm{CO}_{2}$ at $\mathrm{m} / \mathrm{z}=44$ (amplified 5 times) are presented in Figure 12. The results confirmed those obtained by gas-IR: methanol conversion and $\mathrm{CO}_{2}$ production increased 1.5 to 2 times on TNTs in comparaison to $\mathrm{TiO}_{2}-\mathrm{P} 25$ (Figure $12)$.

< Figure 12 here>

\section{Concentration effect}

In order to highlight the concentration effect on methanol photooxidation, $2000 \mathrm{ppm}$ of methanol were sent under the same conditions on TNTs. The gas-IR and MS results are presented in Figure 13. Photooxidation activity was higher than with 5040 ppm of methanol. The $\mathrm{CO}_{2}$ selectivity is also higher and reached $100 \%$ for $\mathrm{T}>90^{\circ} \mathrm{C}$, possibly because of an increase of the Oxidant-species/methanol ratio due to the decrease of methanol concentration.

< Figure 13 here> 
Figure 14 presents the IR spectra of TNTs (and the gas phase of the reaction) before and during the photooxidation at RT and at $120^{\circ} \mathrm{C}$. After UV irradiation new bands appeared at $2870,1715,1650,1560$ and $1370 \mathrm{~cm}^{-1}$. The bands detected at 2870,1560 and $1370 \mathrm{~cm}^{-1}$ are assigned respectively to $v_{\mathrm{s}}(\mathrm{CH}), v_{\mathrm{as}}(\mathrm{COO})$ and $\mathrm{v}_{\mathrm{s}}(\mathrm{COO})$ vibrations of bidentate formate species adsorbed on the catalyst surface. Those observed at 1715 and $1650 \mathrm{~cm}^{-1}$ are assigned to $v(\mathrm{C}=\mathrm{O})$ vibrations of formic acid (or methylformate) hydrogen bonded and co-ordinately bonded to Lewis acid sites, respectively ${ }^{13,25,26,27}$ (the IR spectra vs. time and temperature during photooxidation of methanol at different temperature are presented in Figure I in the supplementary materials). The IR band at $1570 \mathrm{~cm}^{-1}$ reached a maximum at $120^{\circ} \mathrm{C}$ which means that the temperature favours the formation of bidentate formate, thus explaining the increase of methanol photooxidation. These results suggest that the bidentate formate ions are common intermediates and that the photooxidation mechanism could be presented as follows:

$$
\mathrm{TiO}_{2}+\mathrm{hv} \rightarrow \mathrm{h}^{+}+\mathrm{e}^{-} \quad\left(\mathrm{h}^{+}+\mathrm{e}^{-}=\text {electron-hole pair }\right)
$$

In the presence of $\mathrm{O}_{2}$

$$
\mathrm{O}_{2}+\mathrm{e}^{-} \rightarrow \mathrm{O}_{2}^{\bullet-}
$$

Methanol and methoxy species adsorbed $\left(\mathrm{CH}_{3} \mathrm{O}\right)$ on the catalyst surface can react directly with the " $\mathrm{h}^{+}$" holes as already reported in the literature ${ }^{28,29}$ :

$$
\begin{aligned}
& \mathrm{CH}_{3} \mathrm{O}^{-}\left(\mathrm{CH}_{3} \mathrm{O}_{(\mathrm{a})}\right)+\mathrm{h}^{+} \rightarrow \mathrm{CH}_{3} \mathrm{O}^{\bullet} \\
& \mathrm{CH}_{3} \mathrm{O}^{\bullet} \rightarrow \mathrm{CH}_{2} \mathrm{O}^{\bullet-}+\mathrm{H}^{+} \\
& \mathrm{CH}_{2} \mathrm{O}^{\bullet-} \rightarrow \mathrm{H}_{2} \mathrm{CO}+\mathrm{e}^{-}
\end{aligned}
$$

In the presence of $\mathrm{O}_{2}{ }^{\bullet-}$ formaldehyde could be oxidized into $\mathrm{CO}_{2}$ and $\mathrm{H}_{2} \mathrm{O}$ (photocombustion):

$$
\mathrm{H}_{2} \mathrm{CO}+\mathrm{O}_{2}^{\bullet-} \rightarrow \mathrm{CO}_{2}+\mathrm{H}_{2} \mathrm{O}+\mathrm{e}^{-}
$$

$\mathrm{CH}_{3} \mathrm{O}$ and $\mathrm{CH}_{3} \mathrm{OH}$ can be oxidized to form bidentate formate species $\mathrm{HCOO}$ :

$$
\mathrm{H}_{3} \mathrm{O}+\mathrm{O}_{2}^{\bullet-} \rightarrow \mathrm{HCOO}+\mathrm{H}_{2} \mathrm{O}+\mathrm{e}^{-}
$$


HCOO in presence of $\mathrm{CH}_{3} \mathrm{O}^{\bullet}$ leads to the formation of methyl formate:

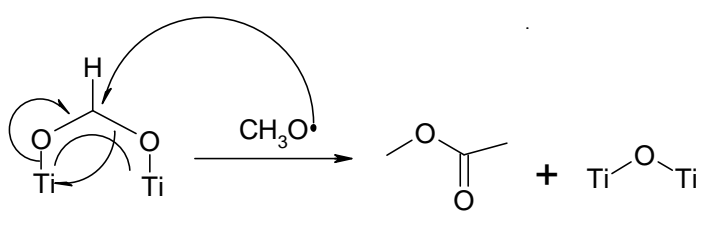

$\mathrm{HCOO}$ in presence of $\mathrm{CH}_{3} \mathrm{OH}$ leads to the formation of formic acid and methoxyl radical:

$$
\mathrm{HCOO}^{\bullet}+\mathrm{CH}_{3} \mathrm{OH} \rightarrow \mathrm{CH}_{3} \mathrm{O}^{\bullet}+\mathrm{HCOOH}
$$

< Figure 14 here>

\section{$U V$-intensity effect}

Figure 15 presents methanol (5040 ppm) photooxidation at RT on TNTs, increasing with UVirradiation intensity (under the same condition as above). Methanol conversion was complete at intensity higher than $3.5 \mathrm{~mW} / \mathrm{cm}^{2}$. The selectivity was also affected by intensity: complete photocombustion was obtained at higher than $5 \mathrm{~mW} / \mathrm{cm}^{2}$. These results could be explained by the increase of the production of oxidant species when intensity increased. It is noteworthy that a high amount of carbonyl species was always detected in the first period of irradiation (whatever the intensity, Figure II, supplementary information). It could be assigned to the high concentration of methanol in the gas phase due to desorption phenomena mentioned above (decrease of [oxydants]/[methanol] ratio). Therefore, an increase of UV-irradiation intensity led to an increase of activity and $\mathrm{CO}_{2}$-selectivity of the photocatalyst.

\footnotetext{
< Figure 15 here>
} 


\section{n-hexane photooxidation and temperature}

n-hexane photooxidation was performed under the same condition as for methanol and the concentration used was $5040 \mathrm{ppm}$. The UV intensity $\left(\mathrm{I}_{0}\right)$ used was $\sim 2 \mathrm{~mW} / \mathrm{cm}^{2}$. The influence of temperature on n-hexane conversion and on $\mathrm{CO}_{2}$ production is presented in Figure 16. Once more TNTs showed higher activity than $\mathrm{TiO}_{2}-\mathrm{P} 25$ for $n$-hexane photodegradation $(\sim 1.5$ times, Table 2). A significant decrease of n-hexane conversion was observed with the increase of temperature (Figure 15). Only $\mathrm{CO}_{2}$ and $\mathrm{H}_{2} \mathrm{O}$ were observed in the gas phase (Figure IIIsupplementary material). This selectivity confirms that carbonyl species observed in methanol photooxidation were produced from the bidentate formate species.

\section{$<$ Figure 16 here >}

Figure 17 presents the evolution of the IR spectra of the photocatalyst surfaces before and during n-hexane photooxidation at different temperatures. After UV irradiation, an important decrease of $\mathrm{CH}$ band has been noted due to desorption phenomena and photooxidation of nhexane. No adsorption of n-hexane was observed on the hydrophilic TiOH sites. After UV irradiation, the $\mathrm{TiOH}$ band has disappeared, perturbed by H-bonding with newly formed hydrophilic species as confirmed by an increase of a broad band at $3660-3000 \mathrm{~cm}^{-1}$. In addition, new IR-bands were visible at $1800-1500 \mathrm{~cm}^{-1}$, ascribed to the adsorption of carbonyl species and unsaturated hydrocarbons. These new bands increased with temperature, whereas the H-bonding seemed to decrease (with no corresponding increase of TiOH IR-band). The formation (and chemisorption) of carbonyl and unsaturated hydrocarbons is favored by heating, resulting in poisoning of the photocatalyst surface (photos of TNTs-pellets before and after photooxidations are presented in Figure IV in supplementary materials). The low increase in $\mathrm{CO}_{2}$ production at temperatures between 45 and $75^{\circ} \mathrm{C}$ (Figure 16) is assigned to the incomplete photooxidation of species adsorbed on $\mathrm{TiO}_{2}$ (n-hexane conversion decreased 
in this temperature range). The increase of the UV intensity from 2 to $3.5 \mathrm{~mW} / \mathrm{cm}^{2}$ led to an increased photooxidation. For $\mathrm{I}_{0}>3.5 \mathrm{~mW} / \mathrm{cm}^{2}$, no significant effect has been observed, showing that residual species on the photocatalyst were poisoning the surface rather than filtering UV light.

\section{< Figure 17 here>}

\section{Carbon monoxide photooxidation}

\section{Intensity effect}

The photooxidation of $1000 \mathrm{ppm}$ of $\mathrm{CO}$ was performed at room temperature at various UV intensities under the same flow conditions as previously. Results are presented in Figure 18. TNTs showed again higher activity than $\mathrm{TiO}_{2}-\mathrm{P} 25$ (1.5-2 times). These results were in good agreement with $\mathrm{CO}_{2}$ production.

< Figure 18 here>

\section{Concentration effect}

The influence of $\mathrm{CO}$ concentration on photooxidation at $\sim 11 \mathrm{~mW} / \mathrm{cm}^{2}$ is presented in Figure 19. CO conversion decreased with increasing CO concentrations. TNTs were again more active than $\mathrm{TiO}_{2}-\mathrm{P} 25$ (Table 2) and the difference was higher when the $\mathrm{CO}$ concentration was lower.

< Figure 19 here>

< Table 2 here> 


\section{Conclusion}

Operando-IR proved to be the ideal technique to study photocatalytic air purification. Coupling this technique to on line analysis (gas-IR and MS) allowed real time monitoring of the species adsorbed on the surface of the photocatalyst and of those formed in the gas phase. Using self supporting photocatalyst wafers and homogenous irradiation gives access to the activity, selectivity and mechanism of the process. Different parameters could be changed (temperature, VOC concentration...) and their influence on the photocatalysis reaction was evaluated. In order to demonstrate the reliability of this technique, two photocatalyst were studied in this work; $\mathrm{TiO}_{2}$-nanotubes (TNTs) as new photocatalyst and $\mathrm{TiO}_{2}-\mathrm{P} 25$ as reference. The IR characterization of TNTs and $\mathrm{TiO}_{2}-\mathrm{P} 25$ allowed understanding the role of surface $\mathrm{TiOH}$ groups in the reaction. Our results indicate an influence of the amount of $\mathrm{TiOH}$ groups on the $\mathrm{TiO}_{2}$ band gap. On the other hand, these sites (especially $\mathrm{Ti}(\mathrm{IV}) \mathrm{OH}$ sites) improve chemisorption of (hydrophilic) methanol and favors its photooxidation. The photooxidation of methanol, n-hexane and carbon dioxide using TNTs and $\mathrm{TiO}_{2}-\mathrm{P} 25$ was performed. TNTs was 1.5 to 2 times more active and selective than $\mathrm{TiO}_{2}-\mathrm{P} 25$ in methanol photooxidation, with improved results at higher temperature and UV-irradiation intensity or at lower methanol concentration. A negative influence of temperature was observed for n-hexane photooxidation, assigned to surface poisoning by unsaturated species (coke). TNTs material were also more active and selective than $\mathrm{TiO}_{2}-\mathrm{P} 25$ for photooxidation of $\mathrm{CO}$ into $\mathrm{CO}_{2}$, with a negative influence of $\mathrm{CO}$ concentration. As conclusion, TNTs material were generally more active and selective than the reference $\mathrm{TiO}_{2}-\mathrm{P} 25$ because of higher surface area. 


\section{Acknowledgement}

The authors wish to thank Prof. S. Bals and Ms. J. Pauwels from EMAT, physics department of the University of Antwerp, Belgium, for recording the TEM picture of TNT. 


\title{
Graphical abstract
}

\author{
New operando-IR techniques to study the photocatalytic activity and selectivity of $\mathrm{TiO}_{2}$ - \\ nanotubes in air purification: influence of temperature, UV intensity and VOC \\ concentration.
}

Mohamad El Roz, Monika Kus, Pegie Cool, Frederic Thibault-Starzyk

A new operando-IR technique has been used to investigate the photocatalytic activity and selectivity of $\mathrm{TiO}_{2}$-nanotubes. Real time IR-monitoring of the photocatalyst surface (identification of surface species) and of the gas phase of the reaction (products identification) gives access to the reaction mechanism and photocatalyst activity and selectivity. Coupling this technique with mass spectrometry gave complementary information on the gas phase during the photocatalytic reaction. The possibility to change and control several parameters (VOCs concentration, UV-intensity and temperature...) led to understand their influence on the reaction, showing the interest of operando-IR technique in photocatalysis studies. $\mathrm{TiO}_{2}$ nanotubes were always more active and selective than the reference $\mathrm{TiO}_{2}-\mathrm{P} 25$. 


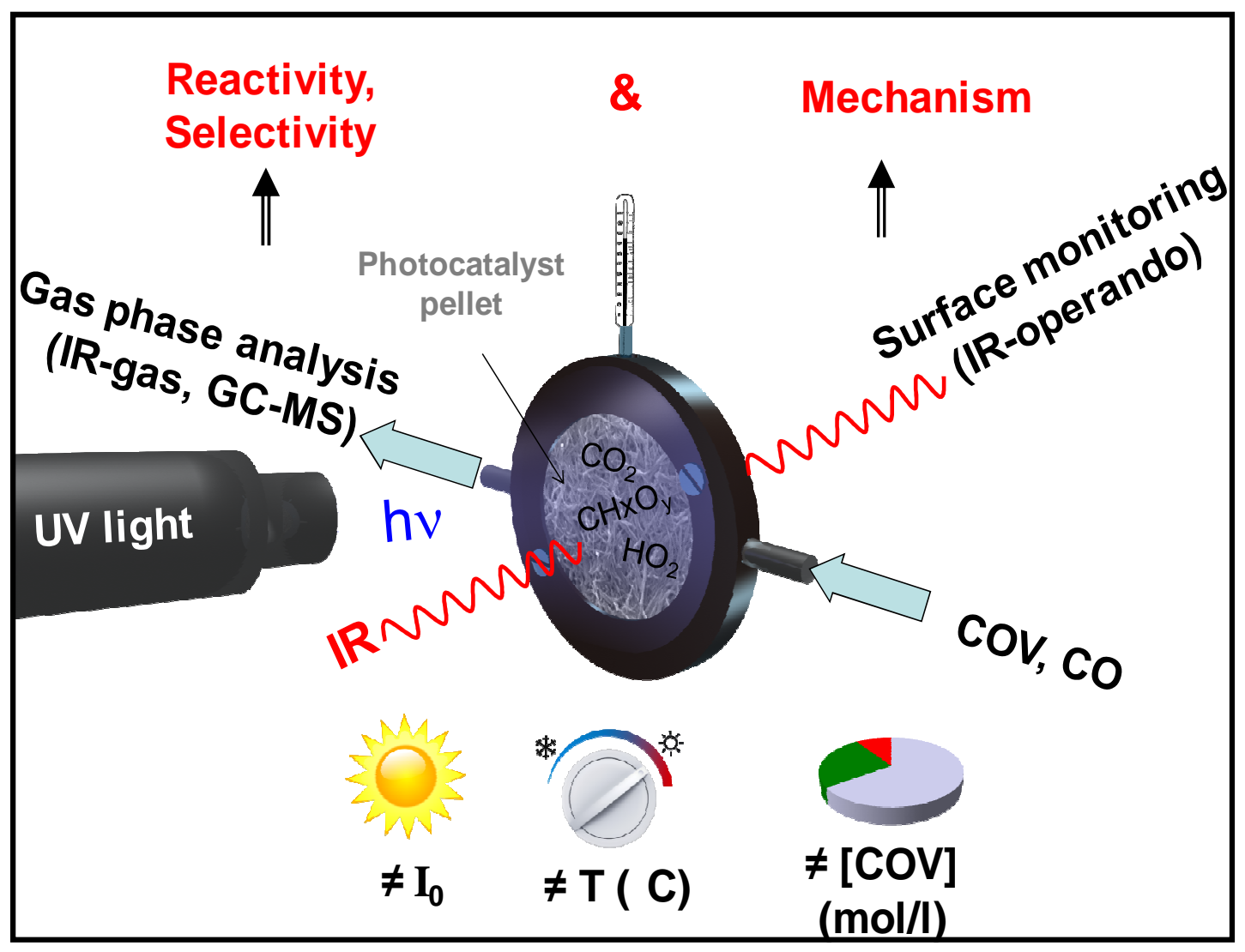




\section{Tables}

Table 1. Height of TiOH IR-bands and area bands of pyridine adsorbed on the TNTs and $\mathrm{TiO}_{2}-\mathrm{P} 25$ surfaces (per $10 \mathrm{mg} / \mathrm{cm}^{2}$ of sample).

\begin{tabular}{|c|c|c|c|c|c|c|}
\hline & \multicolumn{2}{|c|}{ band heigth (a.u.) } & \multicolumn{3}{c|}{ band area $\left(\mathrm{cm}^{-1}\right)$} \\
\hline band $\left(\mathrm{cm}^{-1}\right)$ & $3720 \mathrm{~cm}^{-1}$ & $3690 \mathrm{~cm}^{-1}$ & $1610 \mathrm{~cm}^{-1}$ & $1575 \mathrm{~cm}^{-1}$ & $1491 \mathrm{~cm}^{-1}$ & $1448 \mathrm{~cm}^{-1}$ \\
\hline TNTs & 0,13 & 0,164 & 3 & 0,22 & 0,44 & 2,8 \\
\hline TiO2 & 0,10 & 0,062 & 2,1 & 0,14 & 0,28 & 1,1 \\
\hline ratio & 1,3 & 2,65 & 1,4 & 1,6 & 1,57 & 2,5 \\
\hline
\end{tabular}


Table 2. Reactivity and selectivity of methanol, n-hexane and carbon dioxide photooxidation reactions using $\mathrm{TNTs}$ and $\mathrm{TiO}_{2}-\mathrm{P} 25$ as photocatalysts. (Conv.= conversion; Select. = selectivity.)

\begin{tabular}{|c|c|c|c|c|c|c|}
\hline \multirow{3}{*}{$\begin{array}{c}\mathrm{I}_{0} \sim 2 \mathrm{~mW} / \mathrm{cm}^{2} \\
\text { photocatalyst }\end{array}$} & \multirow{3}{*}{$\mathrm{T}\left({ }^{\circ} \mathrm{C}\right)$} & \multicolumn{5}{|c|}{ Photooxidation of } \\
\hline & & \multicolumn{2}{|c|}{ Methanol } & \multicolumn{2}{|c|}{ n-hexane } & $\begin{array}{c}\mathrm{CO} \\
\text { Conv. }\end{array}$ \\
\hline & & $\begin{array}{l}\text { Conv. } \\
\text { (\%) }\end{array}$ & $\begin{array}{c}\mathrm{CO}_{2} \text {-select. } \\
(\%)\end{array}$ & $\begin{array}{l}\text { Conv. } \\
(\%)\end{array}$ & $\begin{array}{c}\mathrm{CO}_{2} \text {-select. } \\
(\%)\end{array}$ & $\begin{array}{l}\text { Conv. } \\
\text { (\%) }\end{array}$ \\
\hline \multirow{2}{*}{ TNTs } & 30 & $30 \%$ & $85 \%$ & $23 \%$ & $100 \%$ & $25 \%$ \\
\hline & 200 & $75 \%$ & $60 \%$ & $5 \%$ & $100 \%$ & - \\
\hline \multirow{2}{*}{$\mathrm{TiO}_{2}-\mathrm{P} 25$} & 30 & $14 \%$ & $47 \%$ & $12 \%$ & $100 \%$ & $10 \%$ \\
\hline & 200 & $56 \%$ & $44 \%$ & $2 \%$ & $100 \%$ & - \\
\hline
\end{tabular}




\section{Figure captions}

Figure 1. SEM pictures of $\mathrm{TiO}_{2}-\mathrm{P} 25$ (a) and TNTs powders. "(c)" correspond to the TEM picture of TNTs powders.

Figure 2. $\mathrm{XRD}$ results of $\mathrm{TiO}_{2}$-rutile (a) $\mathrm{TiO}_{2}-\mathrm{P} 25$ (b) $\mathrm{TiO}_{2}$-nanotube after calcination (c) and $\mathrm{TiO}_{2}$ nanotube before calcination $(\mathrm{d})$.

Figure 3. Raman results of $\mathrm{TiO}_{2}$-nanotube after calcination (a) and $\mathrm{TiO}_{2}$-nanotube before calcination (b).

Figure 4. $\mathrm{N}_{2}$-sorption isotherms of $\mathrm{TNTs}$ and $\mathrm{TiO}_{2}-\mathrm{P} 25$ samples.

Figure 5. UV-Vis DR spectra of $\mathrm{TiO}_{2}-\mathrm{P} 25$ (a) $\mathrm{TiO}_{2}$-nanotube after calcination (b) and $\mathrm{TiO}_{2}$ nanotube before calcination (c).

Figure 6. IR spectra of $\mathrm{TiO}_{2}-\mathrm{P} 25$ (a) and TNTs (b) under air at RT (1) and after activation under vacuum at $200^{\circ} \mathrm{C}(2)$ (spectra collected after cool down to RT).

Figure 7. (A) Subtraction results of IR spectra of $\mathrm{TiO}_{2}-\mathrm{P} 25$ (a) and TNTs (b) after pyridine adsorption and evacuation under vacuum at $200^{\circ} \mathrm{C}$ (subtraction from the IR spectra of the photocatalysts after activation and before pyridine adsorption). (B) Evolution of the IR-bands height of TiOH bonds vs. temperature after pyridine adsorption.

Figure 8. (A) Evolution of TNTs IR spectra during the methanol adsorption. (B) IR spectra of TNTs (a) and $\mathrm{TiO}_{2}-\mathrm{P} 25$ (b) after methanol saturation.

Figure 9. The IR spectra vs. time (and temperature) of the gas phase during the photooxidation of methanol at different temperatures using the TNTs (A) and $\mathrm{TiO}_{2}-\mathrm{P} 25(\mathbf{B})$ as photocatalyst: The flask corresponds to the turn-on time of the UV-lamp.

Figure 10. IR-gas spectra of the methanol photooxidation reaction before (a) and during (b) irradiation. (c), (d) and (e) correspond to the IR-gas spectra of formaldehyde, methyl formate and formic acid respectively. 
Figure 11. Evolution of the methanol conversion vs. temperature (a) and $\mathrm{CO}_{2}$ selectivity (b), determined using IR spectra of the gas phase, during the methanol photooxidation using TNTs (A) and TiO2-P25 (B) as photocatalysts. ([MeOH] $=5040 \mathrm{ppm}, \mathrm{I}_{0} \sim 2 \mathrm{~mW} / \mathrm{cm} 2$, Flow $=25 \mathrm{~cm}^{3} / \mathrm{min}$ ).

Figure 12. Evolution of the methanol conversion (calculated using the $m / z=31 \mathrm{MS}$ signal) and MS signal of $\mathrm{H}_{2} \mathrm{O}(\mathrm{m} / \mathrm{z}=18)$ (b) and $\mathrm{CO}_{2}(\mathrm{~m} / \mathrm{z}=44)$ (c) at different temperatures during the methanol photooxidation.

Figure 13. IR-gas (A) and MS (B) results obtained during the methanol photooxidation at different temperatures: methanol conversion (a) and (b) $\mathrm{CO}_{2}$ selectivity.

Figure 14. IR spectra of the TNTs (A) and the gas phase (B), before (a) and during irradiation at RT (b) and $120^{\circ} \mathrm{C}(\mathrm{c})$.

Figure 15. (A) Effect of the UV lamp intensities on the methanol conversion (square) and on $\mathrm{CO}_{2}$ (circle) and carbonyl species (diamond) production determined using IR spectra of the gas phase. (B) Original IR spectra of the gas phase during the photooxidation of methanol at different intensities of the UV-lamp at RT temperature.

Figure 16. Evolution of the $\mathrm{n}$-hexane conversion vs. temperature (determined using the IR-gas spectra) and $\mathrm{CO}_{2}$ IR-band area, during the n-hexane photooxidation using TNTs (A) and $\mathrm{TiO}_{2}-\mathrm{P} 25(\mathbf{B})$ as photocatalysts. ([n-hexane $]=5040 \mathrm{ppm}, \mathrm{I}_{0} \sim 2 \mathrm{~mW} / \mathrm{cm}^{2}$, Flow $\left.=25 \mathrm{~cm}^{3} / \mathrm{min}\right)$.

Figure 17. (A) Evolution of the IR spectra of TNTs (I) and $\mathrm{TiO}_{2}-\mathrm{P} 25$ (II) vs temperature during the photooxidation of n-hexane. (B) Subtraction results of the IR spectra of TNTs (I) and $\mathrm{TiO}_{2}-\mathrm{P} 25$ (II) during the photooxidation of n-hexane at RT (a) and $200^{\circ} \mathrm{C}$ (b), from the IR spectrum before UV irradiation. $\left(\mathrm{I}_{0} \sim 2 \mathrm{~mW} / \mathrm{cm}^{2}\right.$; [n-hexane] $=5040 \mathrm{ppm} ; 20 \% \mathrm{O}_{2} / \mathrm{Ar}$, flux $\left.=25 \mathrm{~cm}^{3} / \mathrm{min}\right)$.

Figure 18. (A) Evolution of the $\mathrm{CO}$ photooxidation (close symbol) and $\mathrm{CO}_{2}$ production (open symbol) vs lamp intensities using $\mathrm{TiO}_{2}-\mathrm{P} 25$ (square) and TNTs (circle) as photocatalysts. Figure (B) corresponds to the $\mathrm{CO}_{2}$ evolution in real time at different intensities. 
Figure 19. Evolution of the $\mathrm{CO}$ photooxidation vs. the $\mathrm{CO}$ concentration using $\mathrm{TiO}_{2}-\mathrm{P} 25$ (square) and TNTs (circle) as photocatalysts. $\mathrm{I}_{0}=2 \mathrm{~mW} / \mathrm{cm}^{2}$. 


\section{Figures}

Figure 1
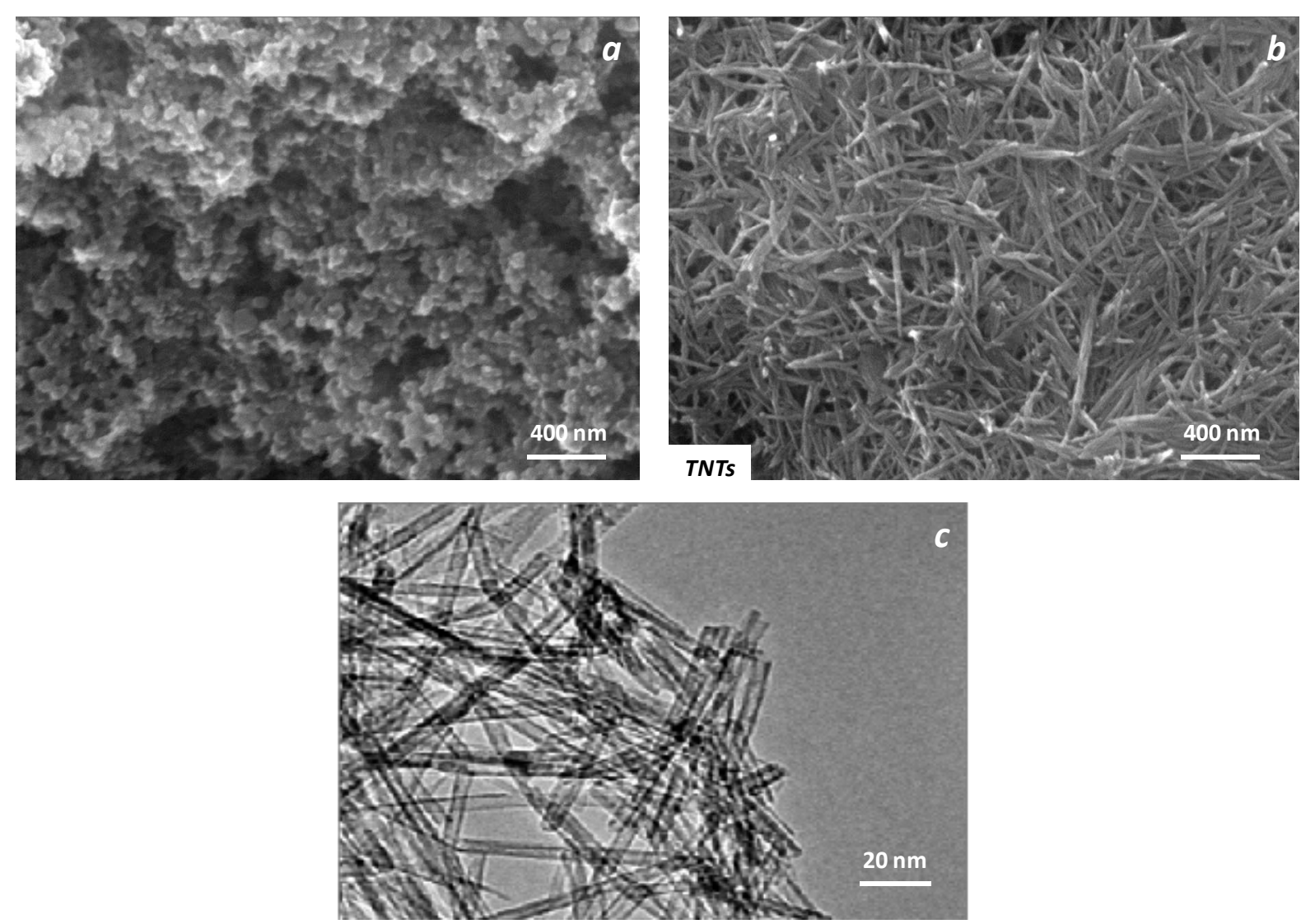
Figure 2

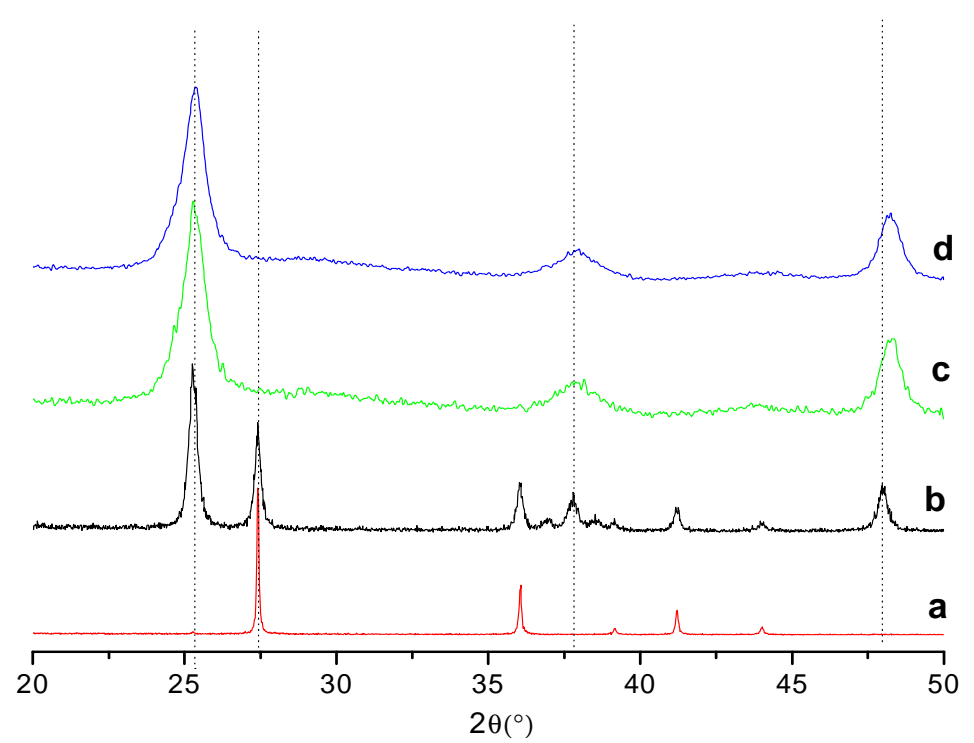

Figure 3

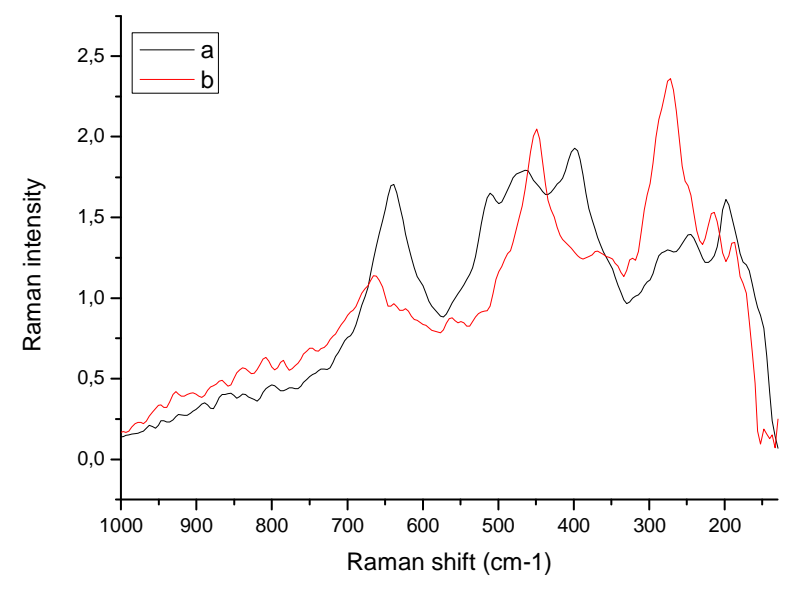


Figure 4

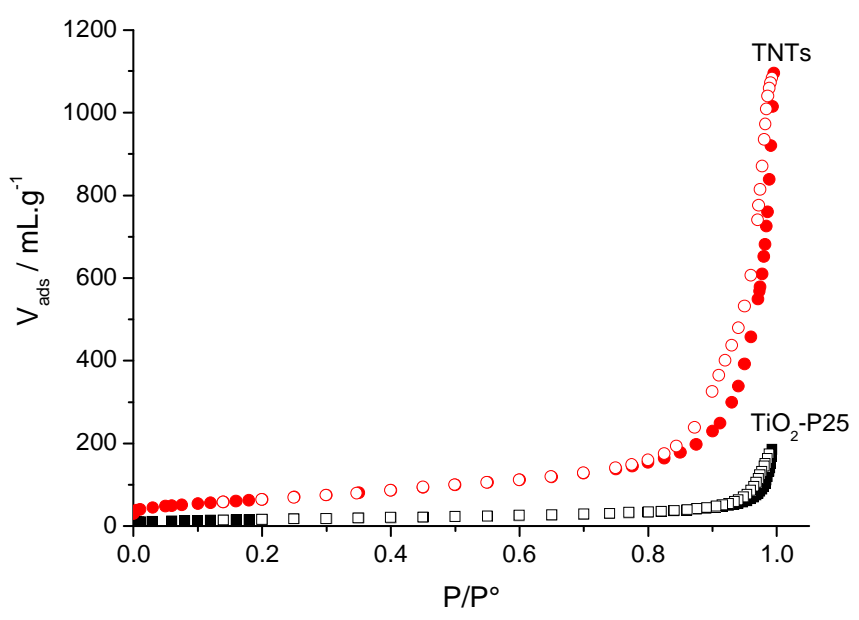

Figure 5

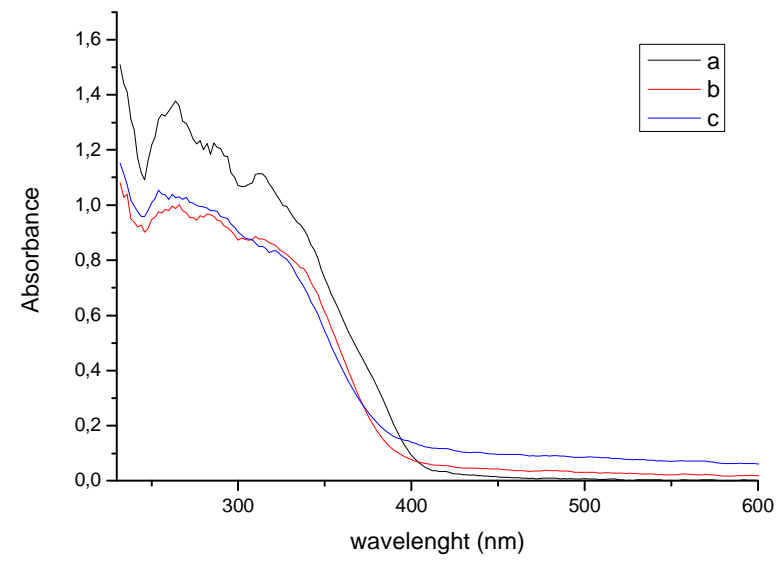




\section{Figure 6}

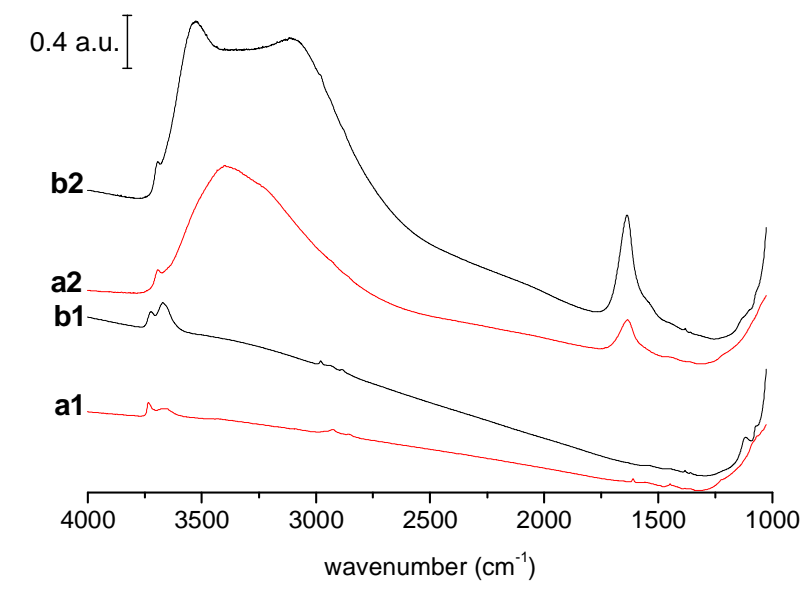

Figure 7

A

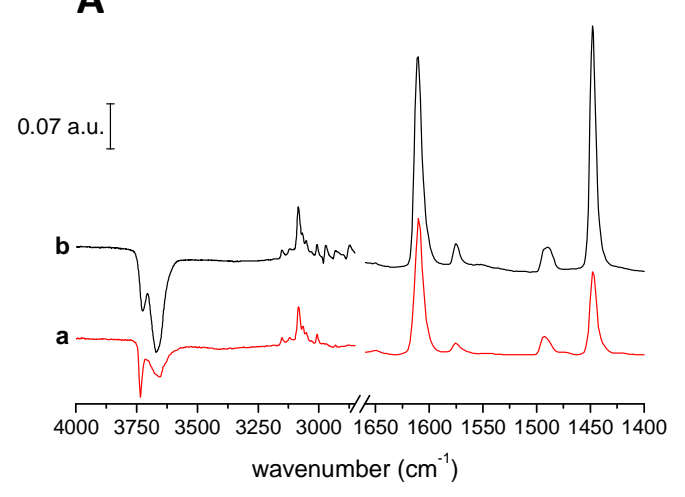

B

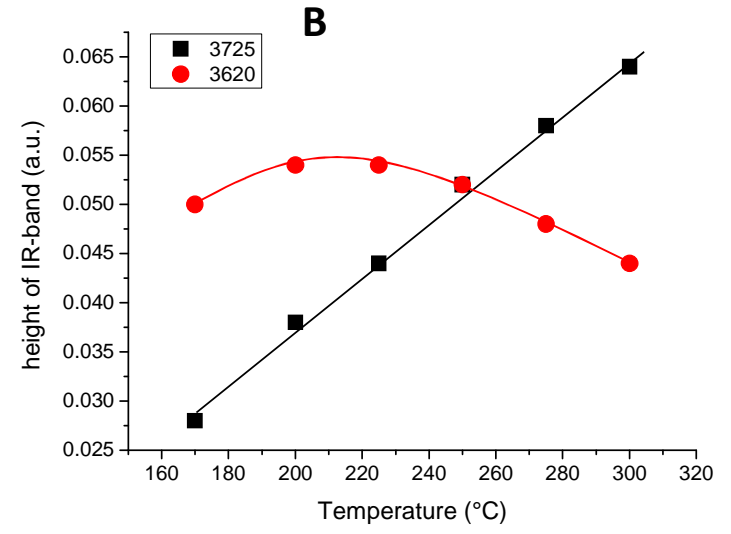


Figure 8

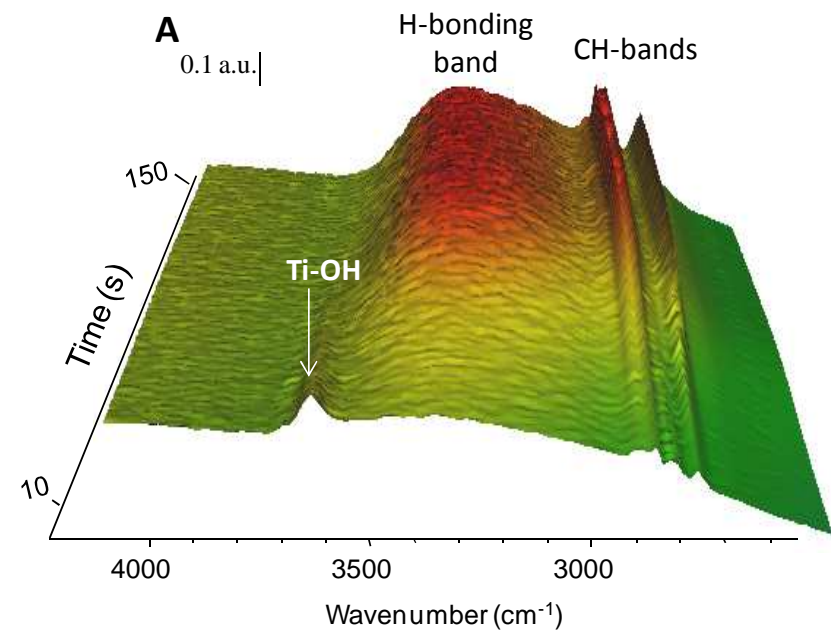

B

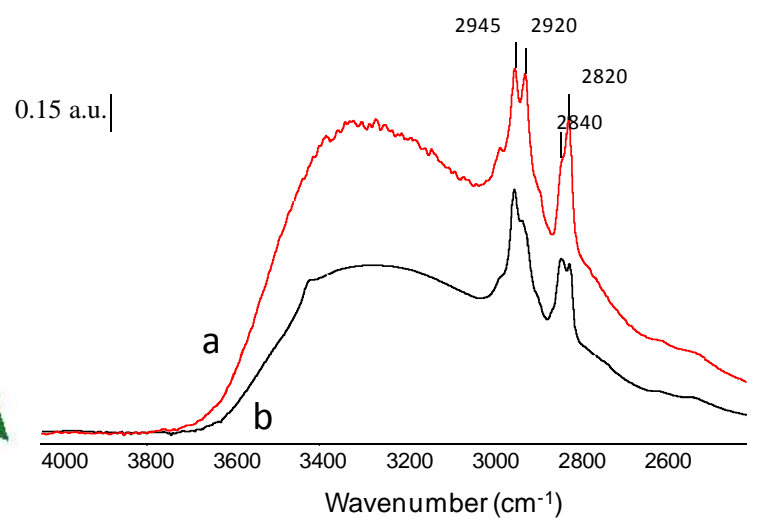




\section{Figure 9}

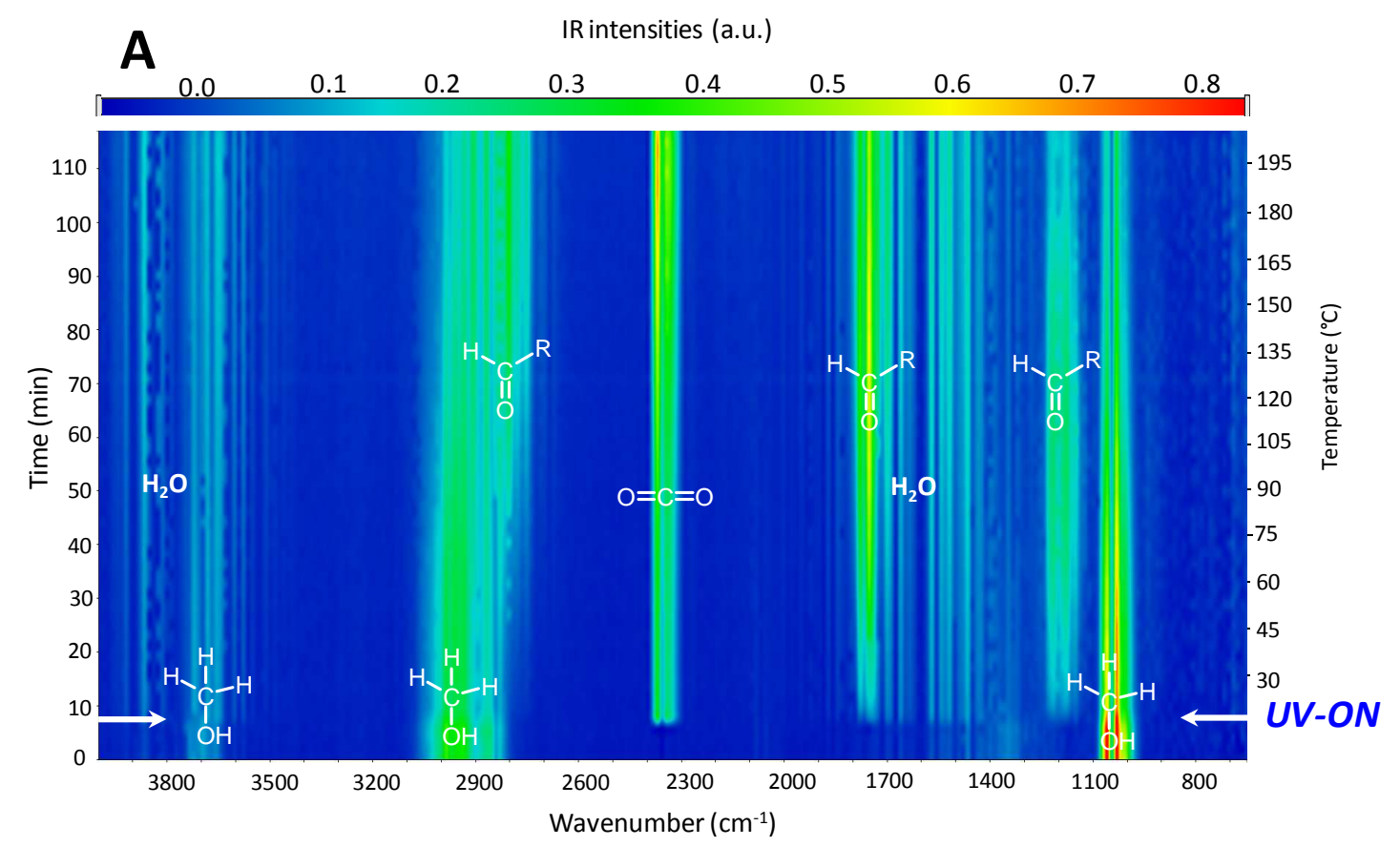

B

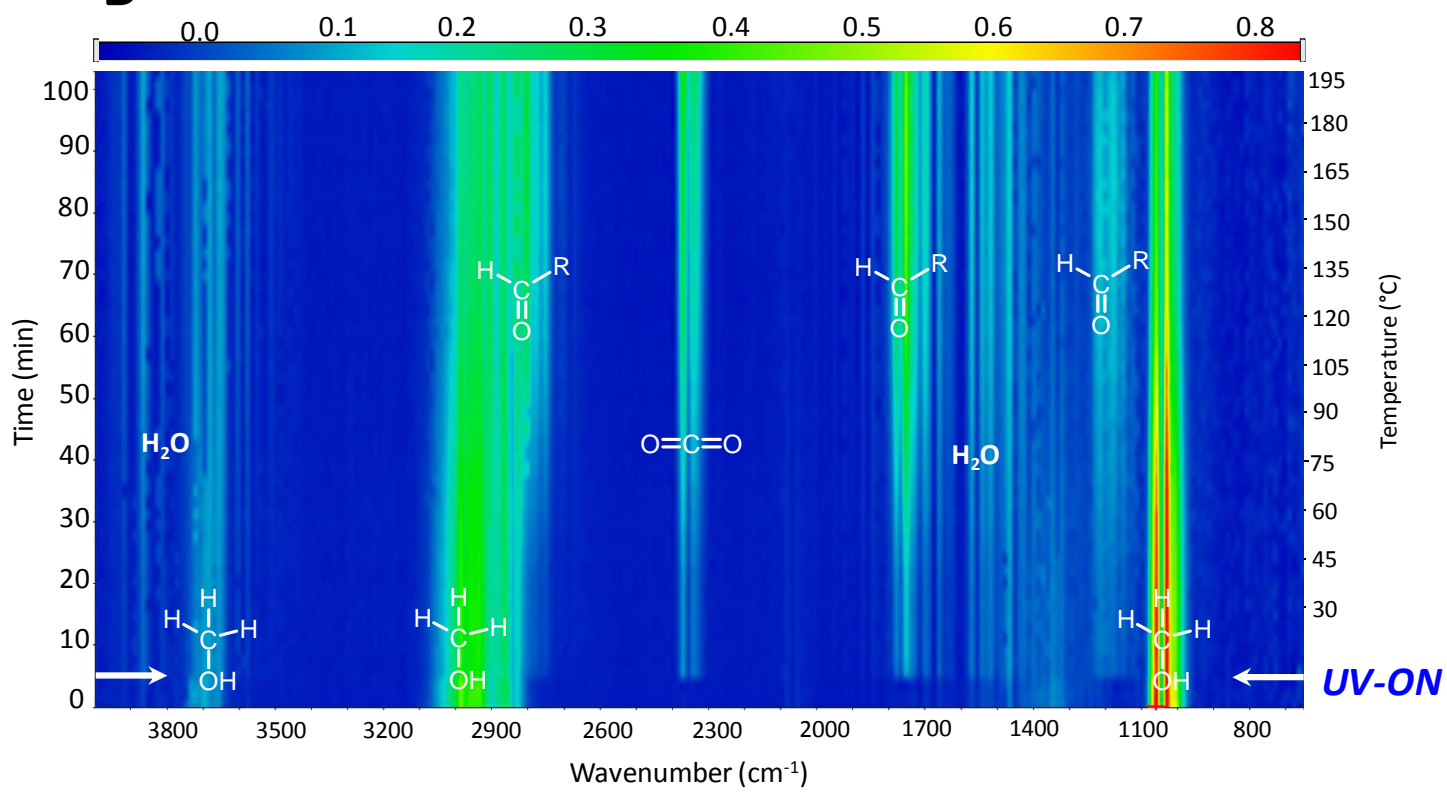




\section{Figure 10}

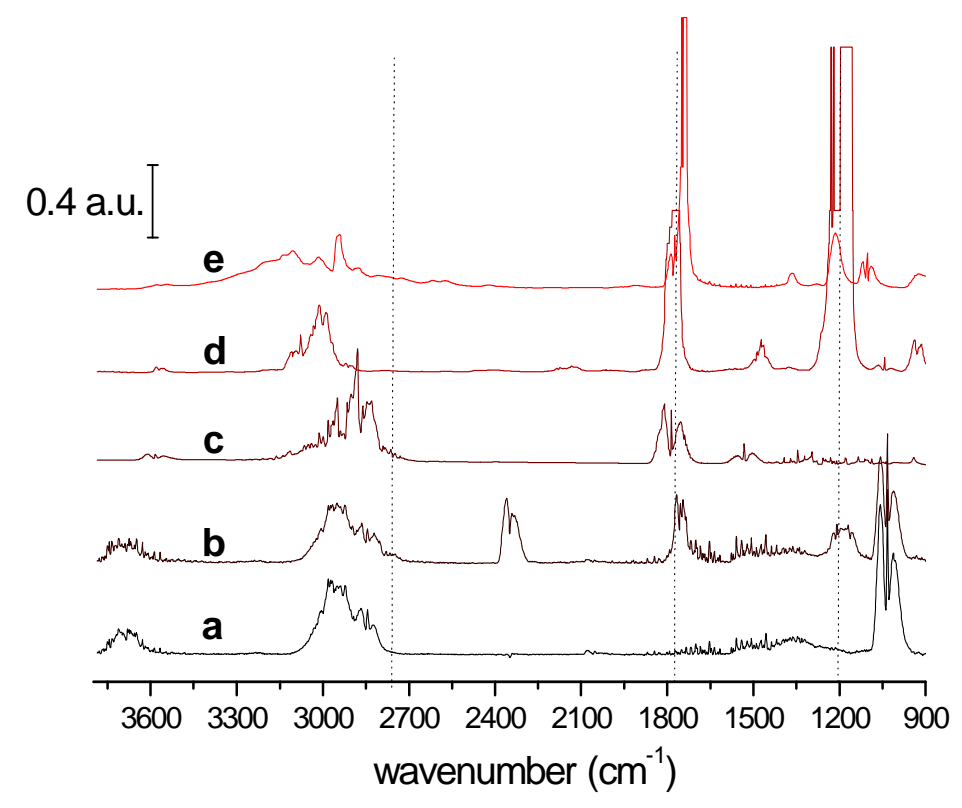

Figure 11

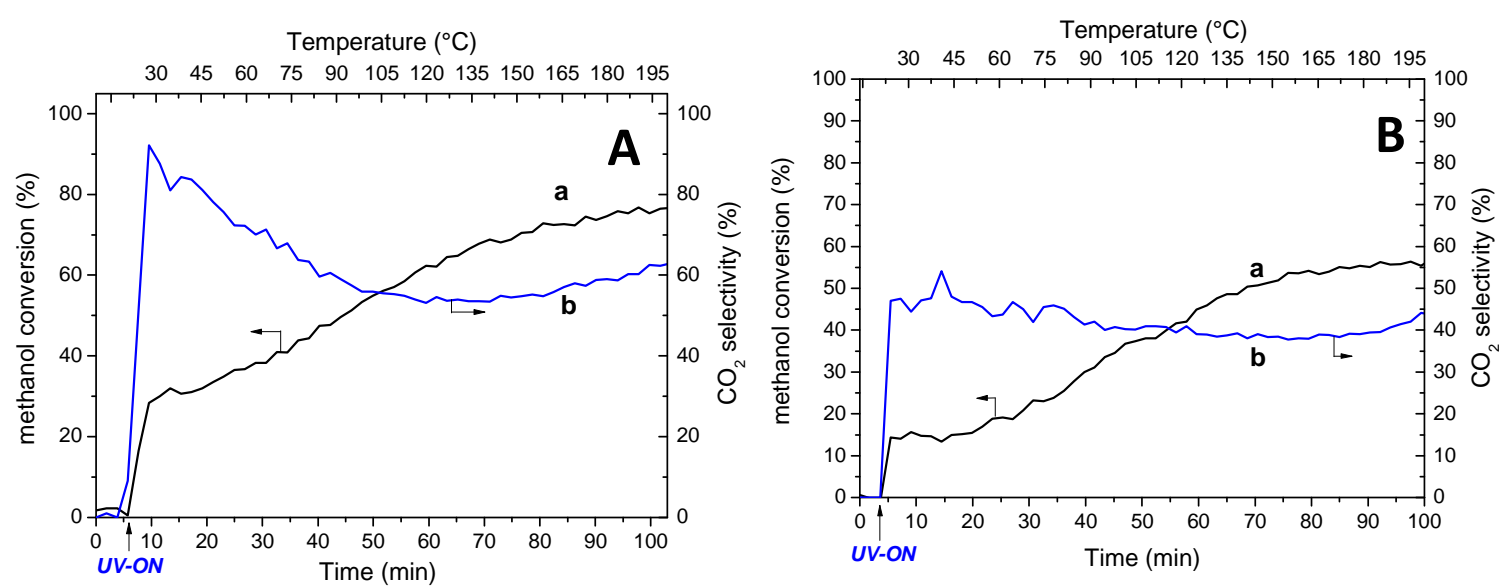




\section{Figure 12}
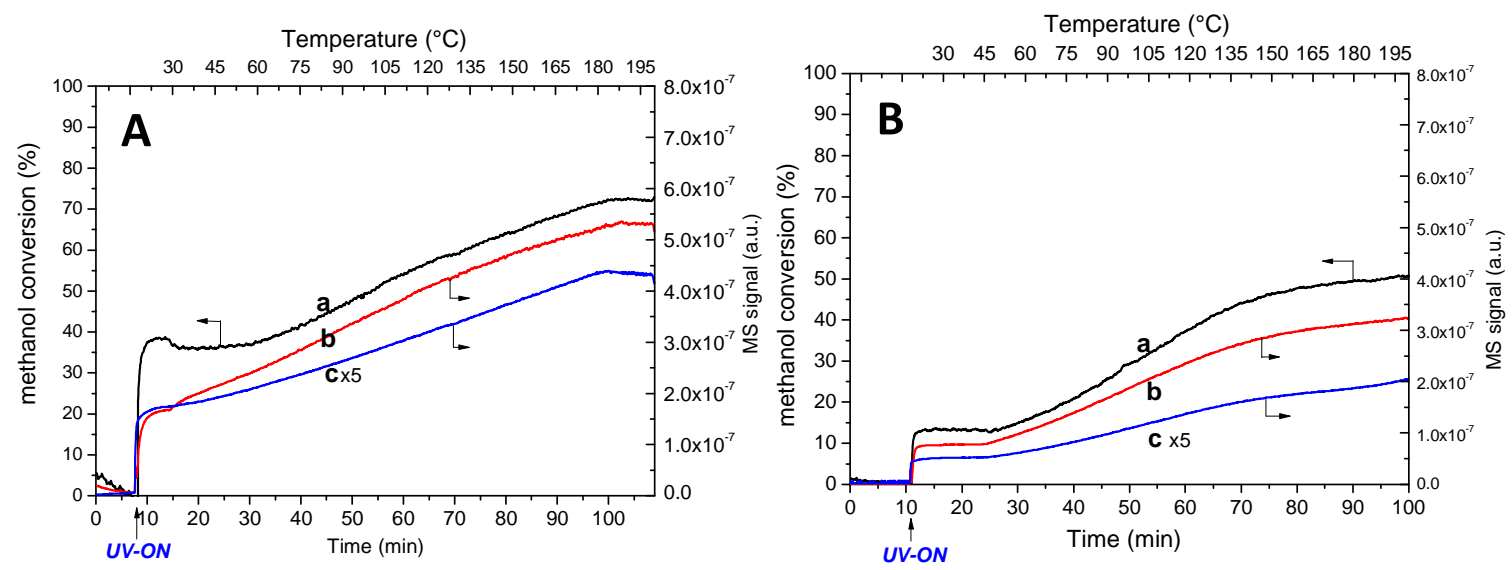

Figure 13

A Temperature $\left({ }^{\circ} \mathrm{C}\right)$

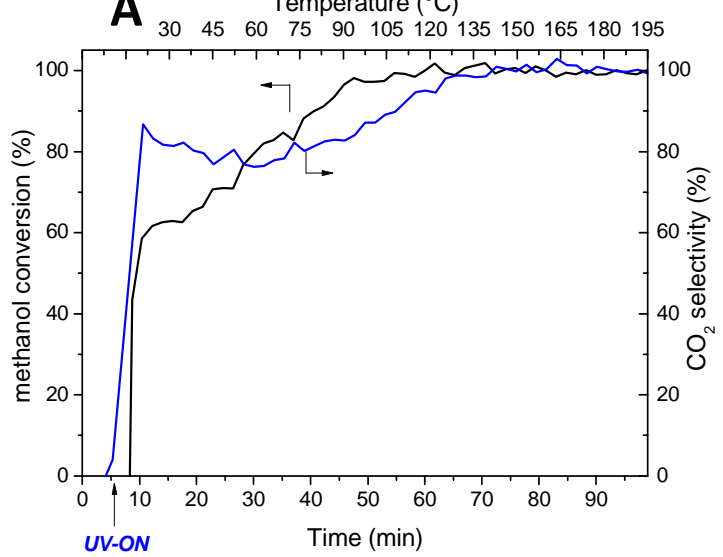

B Temperature $\left({ }^{\circ} \mathrm{C}\right)$

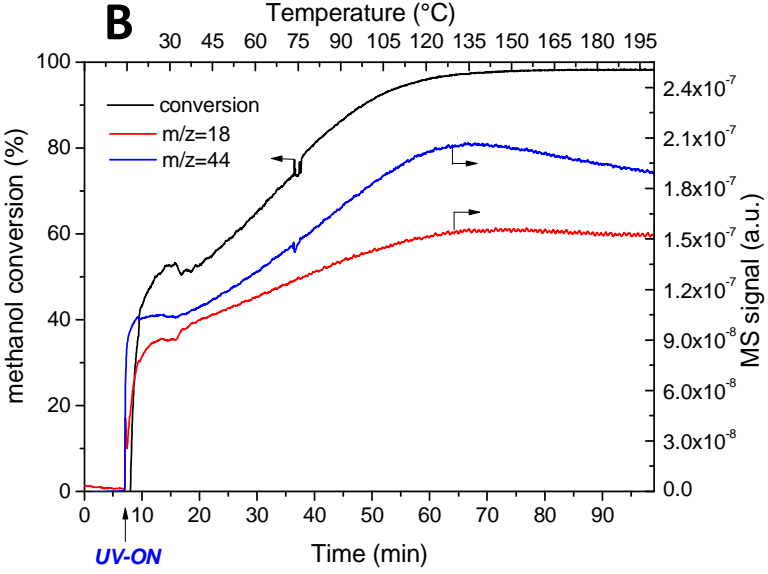




\section{Figure 14}

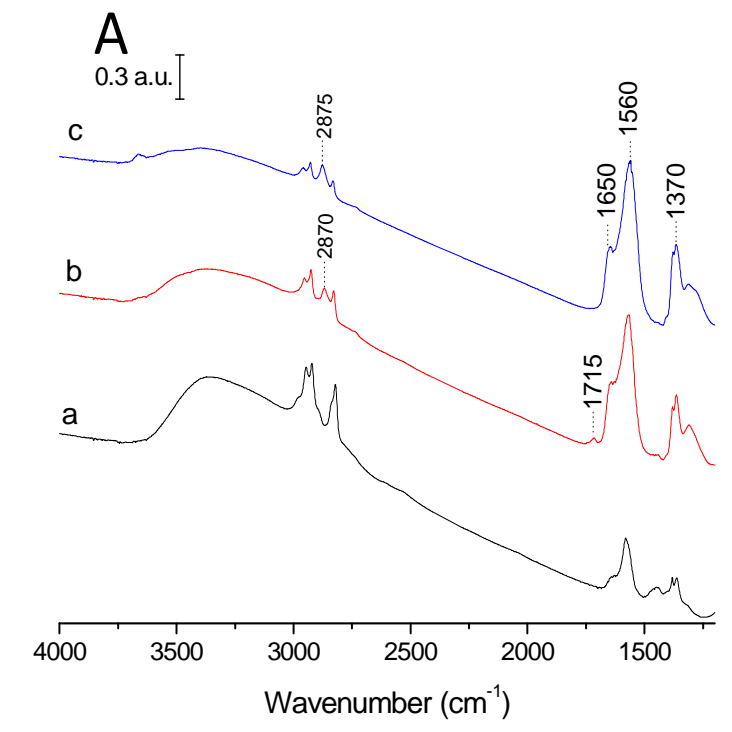

B

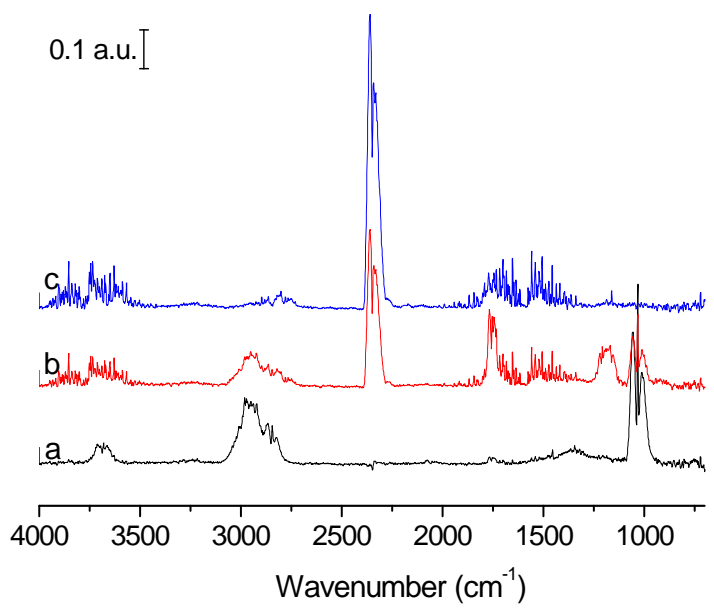

Figure 15
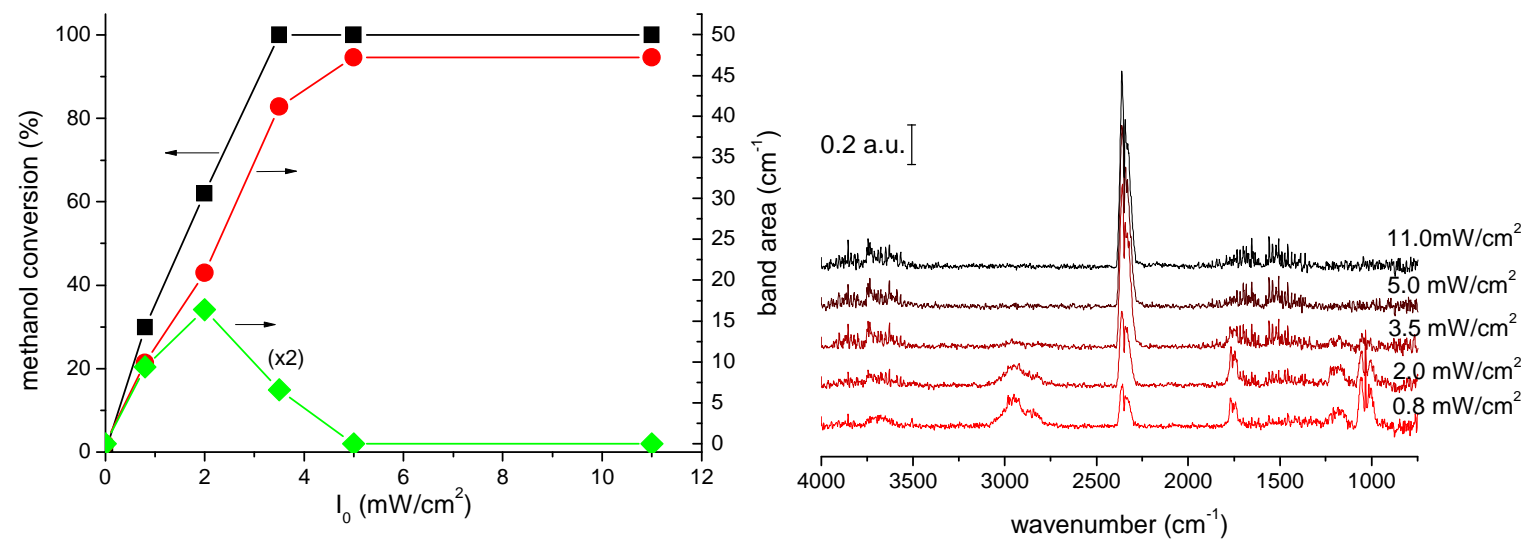


\section{Figure 16}
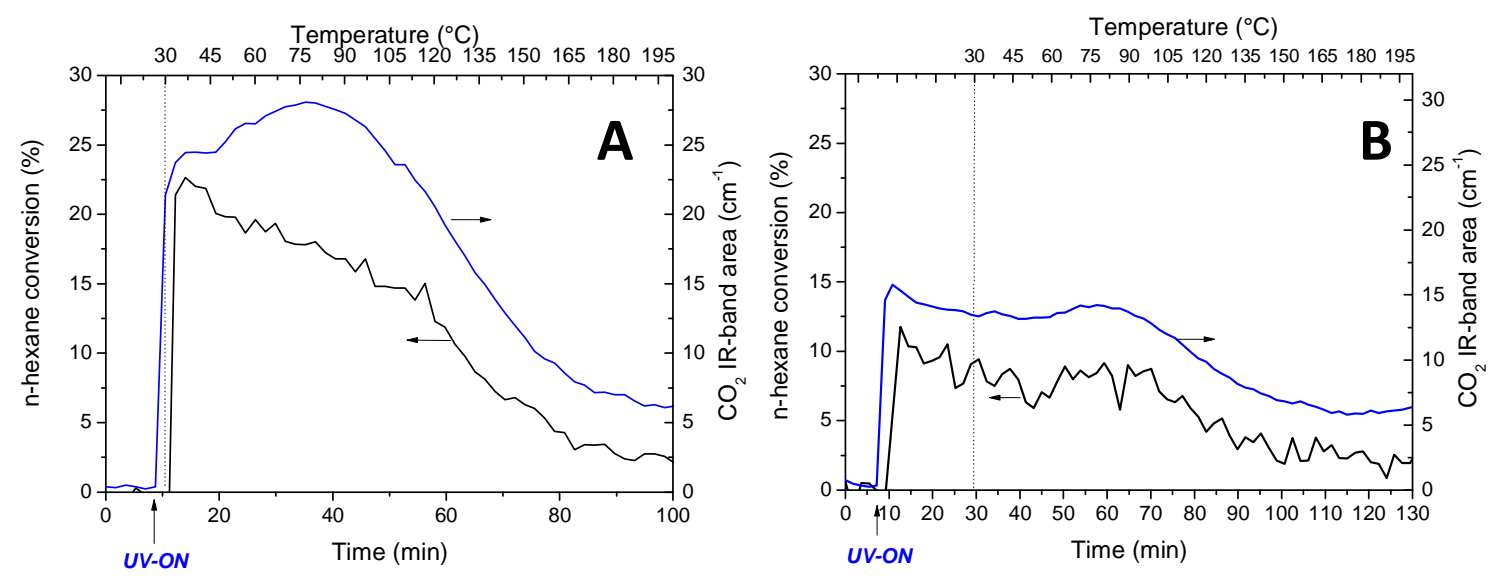

Figure 17
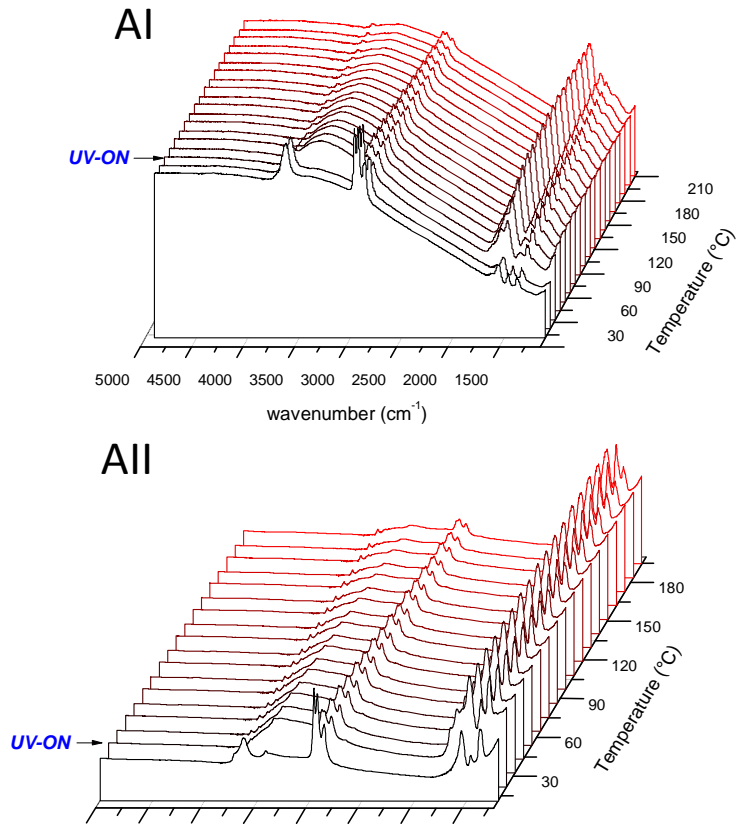

$\begin{array}{llllllll}5000 & 4500 & 4000 & 3500 & 3000 & 2500 & 2000 & 1500\end{array}$
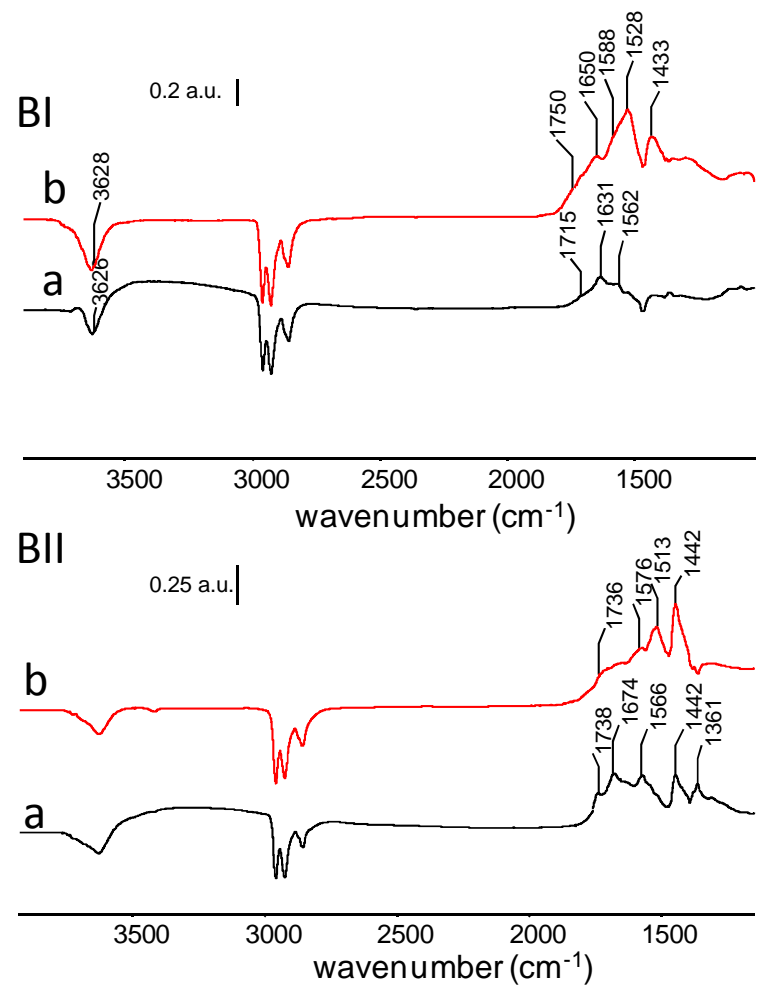
Figure 18

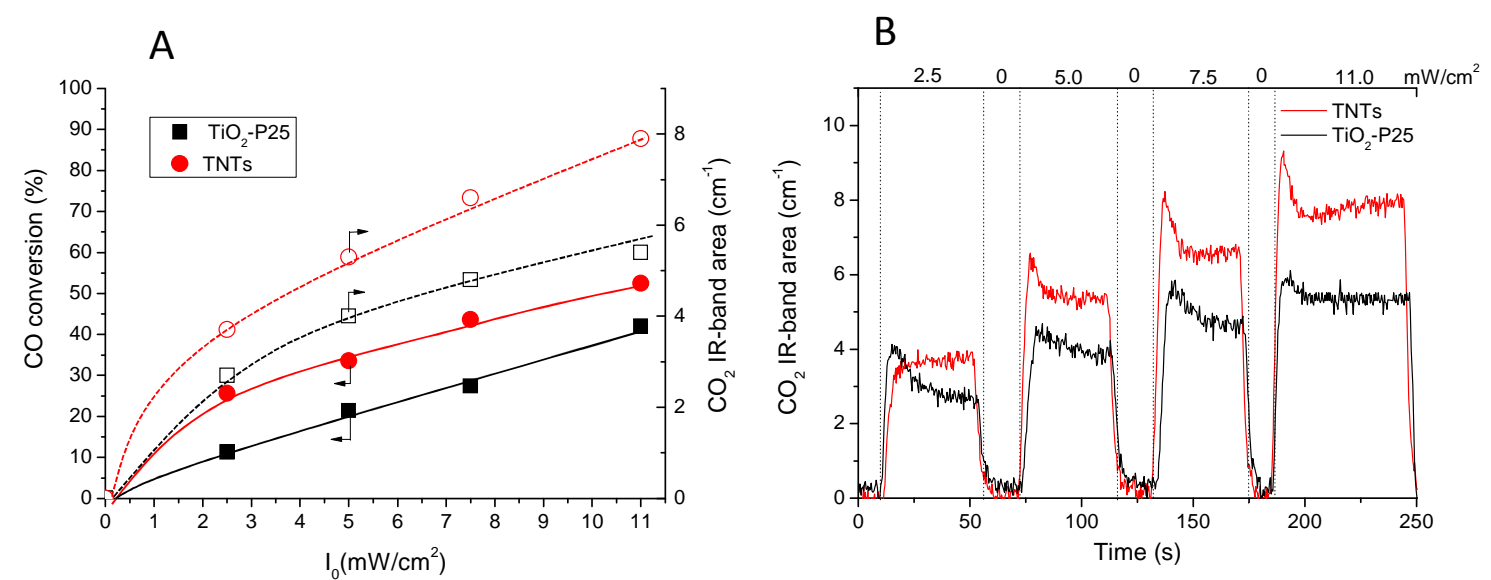

Figure 19

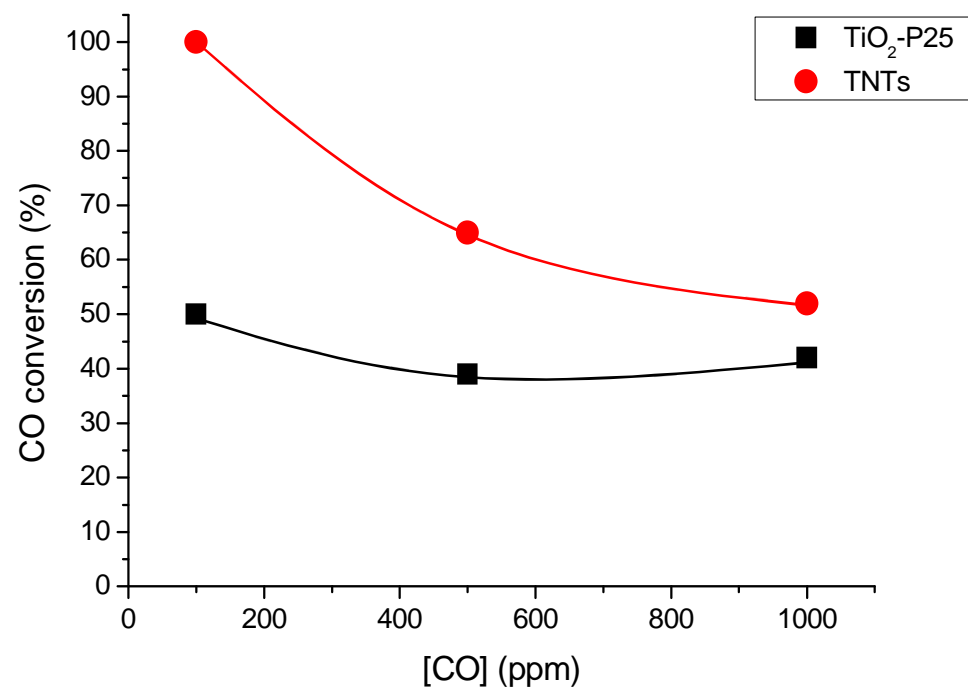




\section{Reference}

1 O’Regan, B.; Graetzel, M. Nature 1991, 353 737-740.
$2 \quad$ Ghicov, A.; Tsuchiya, H.; Hahn, R.; Macak, J. M.; Munoz, A.G.; Schmuki, P.; Electrochem. Commun. 2006, 8, 528-532.

3 Fujishima, A.; Hashimotoand ,K.; Watanabe, T. TiO 2 Photocatalysis. Fundamentals and Applications; BKC, Inc.: Tokyo, 1999.

$4 \quad$ Macak, J. M.; Zlamal, M.; Krysa J.; Schmuki, P. Small 2007, 3, 300-304.

$5 \quad$ Matthews, R.W. J. Phys. Chem. 1987, 91, 3328-3333.

6 Robertson, J.M.C.; Robertson P.K.J.; Lawton, L.A. J. Photochem. Photobiol. A: Chem. 2005, $175,51-56$.

7 Macak, J.M.; Tsuchiya, H.; Ghicov, A.; Yasuda, K.; Hahn, R.; Bauer, S.; Schmuk, P. Curr.Opin. in Solid State and Mater. Sci. 2007, 11, 3-18.

8 Ghicov, A.; Schmuki, P. Chem. Commun. 2009, 2791-2808.

9 Zhang, Z .; Yuan, Y.; Shi, G.; Fang, Y.; Liang, L.; Ding, H.; Jin, A.L. Environ. Sci. Technol. 2007, 41, 6259-6263.

10 Ribbens, S.; Meynen, V.; Van-Tendeloo, G.; Key, X.; Mertens, M.; Maes, B.U.W.; P. Cool, Vansant, E.F. Micro. Meso. Mater. 2008, 114, 401-409.

11 EL-ROZ, M. ; L. Lakiss, Valtchev, V. ; Mintova, S., Thibault-Starzyk, F. Micro. Meso. Mater. In press, DOI: 10.1016/j.micromeso.2012.03.003.

12 Lesage, T.; Verrier, C.; Bazin, P.; Saussey J.; Daturi, M. Phys. Chem. Chem. Phys. 2003, 5, 4435-4440.

13 Chuang, C.C.; Wu, W.C.; Huang, M.C.; Huang, I.C.; Lin, J.L. Journal of Catalysis 1999, $185,423-434$.

14 Thibault-Starzyk, F.; Vimont A.; Gilson, J.P. Catal. Today 2001, 70, 227-241.

15 Szczepankiewicz, S.H.; Moss, J.A.; Hoffman, M.R. J. Phys Chem. B, 2000, 104, 9842-9850.

16 Wu, N.; Lee, M.S.; Pon, Z.J.; Hsu J.Z. J. Photochem. Photobiol. A: Chem. 2004, 163, 277280.

17 Balcerski, W.; Ryu, S.Y.; Hoffman, M.R. Intern. J. Photoenerg. 2008, 2008, 1-9.

18 Wu, B.; Yuan, R.; Fu, X.; J. Sol. St. Chem. 2009, 182, 560-565.

19 Zaki, M. I.; Hasan, M. A.; Al-Sagheer, F. A.; Pasupulety, L. Colloids Surf. A 2001, 190, 261274. 
20 Wang, X.; Kim, S.; Buda, C.; Neurock, M.; Koper, O. B.; J.T. Yates, Jr. J. Phys. Chem. C 2009, 113, 2228-2234.

21 Chuang, C.C.; Chen C.C.; Lin, J.L. J. Phys. Chem. B 1999, 103, 2439-2444.

22 Lavalley, J.C.; Sheppard, N.; Spectrochim. Acta 1972, 28, 2091-2101.

$23 \quad$ Busca, G.; Elmi A.; Forzatti, P.; J. Phys. Chem. 1987, 91, 5263-5269.

$24 \quad$ Lochar, V. Appl.Cata. A: General 2006, 309, 33-36.

25 Popova, G.Y.; Andrushkevich, T.V.; Chesalov, Y.A. ; Stoyanov, E.S. Kinetics and Catalysis, 2000, 41, 805-811.

26 Arana, J.; Dona-Rodriguez, J.M.; Garrigai Cabo, C.; Gonzalez-Diaz, O.; Herrera-Melian J.A.; Perez-Pena, J. Applied Catalysis B: Environmental 2004, 53, 221-223.

27 Arana, J.; Dona-Rodriguez, J.M.; Garrigai-Cabo, C.; Gonzalez-Diaz, O.; Herrera-Melian J.A.; Perez-Pena, J. Applied Surface Science 2004, 239, 60-71.

28 Buzzoni, R.; Bordiga, S.; Ricchiardi, G.; Lamberti, C.; Zecchina A.; Bellussi, G. Langmuir 1996, 12, 930-940.

29 Yamakata, A.; Ishibashi T.; Onishi, H. Int. J. Photoenergy 2003, 5, 7-9. 